\title{
Article \\ Fabrication and Application of Zeolite/Acanthophora Spicifera Nanoporous Composite for Adsorption of Congo Red Dye from Wastewater
}

\author{
Ahmed Hamd 1,2 ${ }^{\text {, Asmaa Ragab Dryaz }}{ }^{3}$, Mohamed Shaban 1,4,*(D), Hamad AlMohamadi ${ }^{5}$, \\ Khulood A. Abu Al-Ola ${ }^{6}$, Nofal Khamis Soliman ${ }^{2}$ iD and Sayed A. Ahmed ${ }^{3}$
}

Citation: Hamd, A.; Dryaz, A.R.; Shaban, M.; AlMohamadi, H.; Abu Al-Ola, K.A.; Soliman, N.K.; Ahmed, S.A. Fabrication and Application of Zeolite/Acanthophora Spicifera Nanoporous Composite for Adsorption of Congo Red Dye from Wastewater. Nanomaterials 2021, 11, 2441. https://doi.org/10.3390/ nano11092441

Academic Editors: Jung Woo Lee and Alexey Pestryakov

Received: 30 June 2021

Accepted: 30 August 2021

Published: 19 September 2021

Publisher's Note: MDPI stays neutral with regard to jurisdictional claims in published maps and institutional affiliations.

Copyright: (c) 2021 by the authors. Licensee MDPI, Basel, Switzerland. This article is an open access article distributed under the terms and conditions of the Creative Commons Attribution (CC BY) license (https:/ / creativecommons.org/licenses/by/ $4.0 /)$.
1 Nanophotonics and Applications Lab, Physics Department, Faculty of Science, Beni-Suef University, Beni-Suef 62514, Egypt; ahmed.hamd@nub.edu.eg

2 Basic Science Department, Nahda University Beni-Suef, Beni-Suef 62764, Egypt; Nofal.Khamis@nub.edu.eg

3 Chemistry Department, Faculty of Science, Beni-Suef University, Beni-Suef 62511, Egypt; drasmaaragab505@gmail.com (A.R.D.); skader_70@yahoo.com (S.A.A.)

4 Department of Physics, Faculty of Science, Islamic University in Madinah, Al-Madinah Al-Munawarah 42351, Saudi Arabia

5 Department of Chemical Engineering, Faculty of Engineering, Islamic University of Madinah, Madinah 42351, Saudi Arabia; ham7171@gmail.com

6 Department of Chemistry, College of Science, Taibah University, Al-Madinah Al-Munawarah 30002, Saudi Arabia; Kabualola@taibahu.edu.sa

* Correspondence: mssfadel@aucegypt.edu

Abstract: Systematic investigations involving laboratory, analytical, and field trials were carried out to obtain the most efficient adsorbent for the removal of congo red (CR) dye from industrial effluent. Modification of the zeolite $(Z)$ by the Acanthophora Spicifera algae (AS; marine algae) was evaluated in terms of adsorption capability of the zeolite to remove CR dye from aqueous solution. The zeolite/algae composite (ZAS) was fabricated using the wet impregnation technique. The AS, Z, and the synthesized ZAS composite were analyzed utilizing various characterization techniques. The newly synthesized ZAS composite has an adsorption capacity that is significantly higher than that of $\mathrm{Z}$ and AS, particularly at low CR concentrations. Batch experiments were carried out to explore the effects of different experimental factors, as well as the dye adsorption isotherms and kinetics. Owing to the presence of intermolecular interactions, the computational analysis showed that the adsorption of the CR molecule on zeolite surfaces is exothermic, energetically favorable, and spontaneous. Furthermore, growing the zeolite surface area has no discernible effect on the adsorption energies in all configurations. The ZAS composite may be used as a low-cost substitute adsorbent for the removal of anionic dyes from industrial wastewater at lower dye concentrations, according to the experimental results. Adsorption of CR dye onto Z, AS, and ZAS adsorbents was adequately explained by pseudosecond-order kinetics and the Langmuir isotherm. The sorption mechanism was also evaluated using Weber's intra-particle diffusion module. Finally, field testing revealed that the newly synthesized adsorbent was $98.0 \%$ efficient at extracting dyes from industrial wastewater, proving the foundation of modern eco-friendly materials that aid in the reuse of industrial wastewater.

Keywords: acanthophora spicifera; zeolite; nanocomposite; Congo red dye adsorption; wastewater treatment; kinetics and isotherms

\section{Introduction}

Water is the planet's primary source of life, as humans are well aware. Although industrialization and innovation improved humanity's way of life, they also discussed the fundamental motivation to pollute clean water resources [1]. Heavy metals, dyes, pharmaceuticals, surfactants, pesticides, personal care items, and other chemicals are not only daily pollutant sources for unpolluted and limited water supplies, but they also harm 
all living beings [2-6]. Synthetic dyes produced from several industries, such as papers, rubbers, textiles, pigments, cosmetics, plastics, and printing, leave behind a large number of pollutants in clean water resources [2,7]. Dyes are used in a wide range of industries to color products and enhance the status of the products $[8,9]$. This extraordinary expansion of utilizing colors prompts water contamination in the environment $[10,11]$. These dyes are toxic, stable, and highly biodegradable [2,12]. Dyes also cause mutagenesis, carcinogenesis, chromosomal breaks, and respiratory poisonousness [13]. Congo red (CR) is an anionic dye that was chosen as a model dye because its color is one of the first contaminants to be identified in wastewater, and the presence of even very minute levels of $C R$ in water is highly recognizable and unacceptable because it prevents water from re-oxygenating. When a person is exposed to Congo red dye, for example, they will experience severe eye irritation, skin irritation, stomach pain, nausea, vomiting, and diarrhea [14]. Various physical, chemical, and biological dye removal procedures have been reported. More precisely, coagulation, reverse osmosis, membrane separation, electrochemical, dilution, filtration, flotation, softening, and reverse osmosis techniques were used for this suggestion [15-17]. In comparison to the other methods, adsorption is the most convenient since it is inexpensive, simple, requires less maintenance, is easy to handle, and creates smaller amounts of sediment [18-26]. Among the used adsorbents, zeolite is a natural adsorbent with porous architectures. In addition to the traditional application of zeolite to soften water, it is used in catalytic processes, membrane separation, alternative zeolite processing, wastewater treatment, antimicrobial applications, construction, coating, pulps, and paper [27-32]. However, its dye adsorption capability is restricted by its compacted structure (low pore volume), which reduces its cationic exchange capacity and adsorption capabilities. Due to the zeolite's surface and the dye molecules' negative charges, the adsorption of anionic dyes on natural zeolite is relatively limited [33]. Various agents have been used to modify the surface of zeolite in order to boost the adsorption capacity of anionic dyes from wastewater. Previously, many reports discussed its modification by different surfactants to improve its sorption properties [34]. However, surfactants used as modifying agents, on the other hand, are commonly synthetic long-chain molecules with limited biodegradability and potential toxicity in the environment.

In recent decades, biomass wastes, fly ash, algae, clay minerals, and agricultural leftovers have all were employed as low-cost and effective adsorbents for removing dye and heavy metals from wastewater [35-38]. Phenols, alkaloids, saponins, flavonoids, and steroids are phytochemical constituents of the Acanthophora Spicifera (AS) marine red alga, and they contain a variety of active functional groups such as carboxylic, hydroxyl, amino, carbonyl, phosphates, and sulfonic [39]. Pollutants could be attracted strongly to the wall of the biomaterials such as AS alga because they contain active functional groups (such as carboxylic, hydroxyl, amino, carbonyl, phosphates, and sulfonic) [40]. Therefore, producing bio-capped zeolite-based adsorbent for dye removal from wastewater is quite important.

In this work, zeolite/algae composite (ZAS) is fabricated using the wet impregnation technique and applied as a nanoadsorbent of $C R$ dye. In order to identify the best-optimized strategy for removing dyes, particularly CR dye, from industrial wastewater, we conducted a comprehensive study that comprised some computational calculations, laboratory, and field studies. To investigate the effect of AS on the uptake capability of $Z$, the adsorption capacity of Z, AS, and ZAS composite to remove the Congo red dye from wastewater was investigated under various experimental conditions. AS and $Z$ were chosen for a variety of factors, including their abundance of natural adsorbent and low cost. Furthermore, the regeneration and reuse costs of $Z, A S$, and ZAS are lower, which may play a significant role in making this a viable operation. Furthermore, reusing a low-cost adsorbent lowers the cost of residue removal. The effects of starting dye concentration, contact time, adsorbent dosage, temperature, $\mathrm{pH}$, and metal adsorption isotherms and kinetics on dye removal were investigated using batch experiments. 


\section{Materials and Methods}

\subsection{Materials}

The El-Nassr company provided zeolite ore for mining, which was used without further alteration. AS algae were collected from the intertidal zone of the Egyptian Red Sea shores. Sigma-Aldrich provided the Congo red dye, which was dissolved in distilled water. Sigma-Aldrich supplied sodium hydroxide granules with a purity of $99.99 \%$ and hydrochloric acid (36\%) for $\mathrm{pH}$ adjustment (Sigma-Aldrich, Munich, Germany).

\subsection{Preparation of Zeolite/Algae (ZAS) Composite}

The zeolite/algae composite (ZAS) was fabricated using the wet impregnation technique $[41,42]$. The following steps were used to make the zeolite/algae composite: in the first step, $1 \mathrm{~g}$ of zeolite and $1 \mathrm{~g}$ of algae were mixed in $20 \mathrm{~mL}$ of distilled water and stirred on a magnetic stirrer at $500 \mathrm{rpm}$ for $60 \mathrm{~min}$, then in ultrasonic for $60 \mathrm{~min}$ and repeated three times, after which the zeolite/algae composite was filtered and washed several times with distilled water and dried in a vacuum oven at $60^{\circ} \mathrm{C}$ for $24 \mathrm{~h}$.

\subsection{Preparation of the Adsorbate}

Congo red (CR), a common anionic dye, was used as the adsorbate in this experiment. Congo red dye is the sodium salt of 3,30-([1,10-biphenyl]-4,40-diyl) bis (4-amino naphthalene-1-sulfonic acid) with a formula: $\mathrm{C}_{32} \mathrm{H}_{22} \mathrm{~N}_{6} \mathrm{Na}_{2} \mathrm{O}_{6} \mathrm{~S}_{2}$. The structure of the dye molecule is shown in Figure S1 (Supplementary Materials). A $1000 \mathrm{mg} / \mathrm{L}$ stock solution was made by dissolving the required amount of CR $(1000 \mathrm{mg})$ in a liter of distilled water. Working solutions were made by diluting the stock solution with distilled water to achieve the desired concentration. The $\mathrm{pH}$ of the solutions was adjusted to $3,5,7$, and 10 using either $0.1 \mathrm{M} \mathrm{HCl}$ or $0.1 \mathrm{M} \mathrm{NaOH}$ solutions. The $\mathrm{pH}$ values were measured by a $\mathrm{pH}$ meter.

\subsection{Samples Characterizations}

The Z, AS, and ZAS composites were characterized using X-ray diffraction (XRD), Scanning electron microscopy (SEM), Fourier transformer infrared (FTIR) spectrometer, and optical spectroscopy. The XRD measurements were performed using the PANalytical diffractometer (Empyrean) that used $\mathrm{Cu}(\mathrm{K} \alpha)$ source with a wavelength $\lambda \alpha=0.154045 \mathrm{~nm}$ and operated at $40 \mathrm{kV}, 35 \mathrm{~mA}$, and scan step of $0.02^{\circ}$ between $20^{\circ}$ and $70^{\circ}$. The average crystallite sizes, Ds, of the prepared nano-adsorbents were obtained by Scherer formula, Ds $=0.94 \lambda \alpha / \beta w \cos \Phi$; where $\beta w$ and $\Phi$ are the corrected full width at half maximum and the diffraction angle [43]. Quanta FEG 250 microscope (Switzerland) was used to measure SEM micrographs. The dry KBr pellet method was used to measure FT-IR spectra by a Bruker VERTEX 70 FT-IR spectrophotometer.

\subsection{Adsorption Studies}

Four adsorption experiment sequences were performed on Z, AS, and ZAS adsorbents under diverse adsorption circumstances. Table S1 shows the adsorption parameters that were investigated: starting CR concentration, reaction temperature, adsorbent dosage, and starting $\mathrm{pH}$ value (Supplementary Materials). All CR adsorption investigations were conducted in batch mode with continuous shaking and varied adsorption parameters such as CR starting concentration (5-25 mg/L), adsorption period (up to $480 \mathrm{~min}$ ), adsorbent dose (0.01-0.05 g per $20 \mathrm{~mL}$ of CR solution), $\mathrm{pH}(3-10)$, and temperature $\left(25-90^{\circ} \mathrm{C}\right)$. In each experiment, the CR solution volume was set at $20 \mathrm{~mL}$. Tracking the absorption peak using a Perkin Elmer Lambda $950 \mathrm{UV} /$ Vis/NIR spectrophotometer revealed the variation in $\mathrm{CR}$ concentration. The reusability tests of $\mathrm{Z}, \mathrm{AS}$, and ZAS adsorbents were tested for four cycles at $25^{\circ} \mathrm{C}$ and pH7 with $20 \mathrm{mg}$ of each, $20 \mathrm{~mL}$ of $10 \mathrm{mg} / \mathrm{L}$ starting CR concentration, and $480 \mathrm{~min}$ reaction time. After each cycle; the adsorbent was removed from the solution, rinsed with distilled $\mathrm{H}_{2} \mathrm{O}$, and set for the next cycle. Equations (1) and (2) were used to 
calculate the CR uptake amounts at equilibrium $\left(\mathrm{q}_{\mathrm{e}}\right)$ and after a period $\mathrm{t}\left(\mathrm{q}_{\mathrm{t}}\right)$, as well as the CR removal\% [44,45]:

$$
\begin{gathered}
\mathrm{q}_{\mathrm{i}}=\left(\mathrm{C}_{\mathrm{o}}-\mathrm{C}_{\mathrm{i}}\right) \frac{\mathrm{V}}{\mathrm{m}} ; \mathrm{i}=\mathrm{e}, \mathrm{t} \\
\text { CR dye removal } \%=\frac{\left(\mathrm{C}_{\mathrm{o}}-\mathrm{C}_{\mathrm{t}}\right)}{\mathrm{C}_{\mathrm{o}}} \times 100
\end{gathered}
$$

at which $C_{o}$ is the starting $C R$ concentration in $m g / L$, and $C_{i}$ is the concentration of $C R$ after period $\mathrm{t}(\mathrm{i}=\mathrm{t})$ and at equilibrium $(\mathrm{i}=\mathrm{e}) . \mathrm{V}$ and $\mathrm{m}$ are the $\mathrm{CR}$ volume in milliliters, and the ZAS mass in milligrams, respectively. The data points shown are the averages of three different trials.

\subsection{Adsorption Isotherms}

Langmuir, Freundlich, and Tempkin models were used to explain the reaction isotherms of the designed Z, AS, and ZAS nanocomposite for the examined CR [46-48]. All linear isotherms equations and their parameters are explained in the Supplementary Materials. The value of the dimensionless separation factor $\left(R_{L}\right)$ based on Equation (3) could be used to predict the degree of favorability of the Langmuir isotherm for equilibrium data [49].

$$
\mathrm{R}_{\mathrm{L}}=\frac{1}{\left(1+\mathrm{K}_{\mathrm{L}} \mathrm{C}_{\max }\right)}
$$

where $\mathrm{C}_{\max }$ denotes the maximum initial $\mathrm{CR}$ concentration, and $\mathrm{K}_{\mathrm{L}}$ represents the Langmuir constant. The $\mathrm{K}_{\mathrm{L}}$ is a measure of the adsorbate ion affinity to the adsorption sites. Strong adsorption is indicated by a higher $\mathrm{K}_{\mathrm{L}}$ value, whereas weak adsorption interaction is indicated by a lower $K_{L}$ value. Unfavorable sorption is denoted by a value of $R_{L}>1$, linear sorption by a value of $R_{L}=1$, favorable sorption by a value of $0<R_{L}<1$, and irreversible sorption by a value of $R_{L}=0 . R_{L}>1$ refers to unfavorable sorption, $R_{L}=1$ refers to linear sorption, $0<R_{L}<1$ refers to favorable sorption, and $R_{L}=0$ refers to irreversible sorption process.

\subsection{Adsorption Kinetics and Mechanism}

Several adsorption processes and kinetics models, including intra-particle diffusion, pseudo-first-and second-order models, and the Elovich kinetic model, are examined to determine the adsorption mechanisms and kinetics that fit the $\mathrm{CR}$ adsorption onto $\mathrm{Z}$, AS, and ZAS adsorbents [4,50-55]. All linear kinetics equations and their parameters are explained in Supplementary Materials. The average values of all adsorption findings were measured in triplicates. The values of regression coefficients $\left(R^{2}\right)$ for various kinetic and isotherm models were obtained using OriginPro 2018's statistical functions.

\subsection{Computational Calculations}

For the optimization of clinoptilolite and $\mathrm{CR}$ structures using density functional theory (DFT), the Generalized Gradient Approximation-Perdew-Burke-Ernzerhof (GGAPBE) function was chosen. The method of choice was the dual numerical basis with polarisation (DNP). The spin-polarization effects were ignored when modeling the exchange/correlation function. Effective core potentials approximation was used to manage the core electrons of the clinoptilolite and CR structures. The DMol3 module of the Biovia Materials Studio was used to perform these calculations [56-58]. This investigation generated the original structure of zeolite clinoptilolite [59]. Zeolite unit cell bulk structure was subjected to energy minimization followed by simple box nanoclusters creation with sizes 7,5 and $3 \mathrm{~nm}$ using a builder inherent in the studio software, as follows: simple box, $70 \AA(X, Y, Z$ directions $=70 \AA, K=684, \mathrm{Na}=6112, \mathrm{Si}=468, \mathrm{O}=8834, \mathrm{Ca}=644, \mathrm{Al}=3214$, $\mathrm{H}=2720$ atoms), $50 \AA$ ( $\mathrm{X}, \mathrm{Y}, \mathrm{Z}$ directions $=50 \AA, \mathrm{K}=249, \mathrm{Na}=492, \mathrm{Si}=2213, \mathrm{O}=5520$, $\mathrm{Ca}=270, \mathrm{Al}=1342, \mathrm{H}=1044$ atoms $)$ and $30 \AA(\mathrm{X}, \mathrm{Y}, \mathrm{Z}$ directions $=30 \AA, \mathrm{K}=64, \mathrm{Na}=132$, $\mathrm{Si}=468, \mathrm{O}=1220, \mathrm{Ca}=56, \mathrm{Al}=522, \mathrm{H}=224$ atoms). The Monte Carlo (MC) simulation 
software was used to investigate the effect of varying clinoptilolite sizes on the energy of adsorption and to precisely place the active desorption sites of CR on the clinoptilolite surface. The Adsorption Locator module in Materials Studio was used to run the MC simulations, with the COMPASS force field as the force field and the current as the charge sector. The essential ideas of MC simulation were developed by Frenkel and Smit [60].

\subsection{Field Experiments}

The newly synthesized nanocomposite was tested as an effective eco-friendly adsorbent that could be applied on a large scale to remove industrial waste dye from industrial wastewater. To this end, wastewater containing waste dye was obtained from a clothing dying plant in Beni-Suef city, and the wastewater containing waste dye was used as is, with no further treatment or dilution. Based on our modified computational and experimental findings, the best nanoadsorbent system was chosen.

\section{Results and Discussion}

\subsection{Characterization of the Adsorbents}

\subsubsection{Morphological Properties}

The SEM images of Z, AS, and ZAS adsorbent are shown in Figure 1. The SEM images of zeolite (Figure 1a,b) show agglomerated rounded regular shape particles, rough surfaces, different particle sizes, and nanoporous cavities on the surface. The diameters of the nanopores ranged from 37.2 to $93.1 \mathrm{~nm}$. Figure 1c,d shows that AS has a less rough surface with two sequences of nanopores, which impacts the surface area of AS and thus its adsorption capacity. The diameters of the large pore sequences range from 369.1 to $473.8 \mathrm{~nm}$, while the diameters of the fine pore sequences range from 68.9 to $107.1 \mathrm{~nm}$. When zeolite is treated with AS algae, the SEM images of the composite (Figure 1e,f) show that the pores in the AS surface are filled or covered with agglomerated zeolite particles. The diameters of the observed pores on the surface of the composite are $294.3 \pm 56.7 \mathrm{~nm}$. The formation of the ZAS composite could be confirmed by the observed changes in the morphological features of the composite as compared to that of $Z$ and AS (Figure 1). The hydrodynamic diameter and particle size distribution of the Z, AS, and ZAS are estimated using the DLS technique (Supplementary Materials Figure S2). The average hydrodynamic diameters of Z, AS, and ZAS are $80.4,115.1$, and $110.9 \mathrm{~nm}$, respectively. Furthermore, the PET surface areas of Z, AS, and ZAS are $\sim 91,187$, and $174 \mathrm{~m}^{2} / \mathrm{g}$, respectively.

\subsubsection{X-ray Diffraction Characterization}

XRD charts of Z, AS, and ZAS adsorbent are shown in Figure 2a. The characteristic diffraction peaks of zeolite mineral appear $2 \Phi$ of $\sim 9.9^{\circ}, 22.4^{\circ}, 26.2^{\circ}, 26.8^{\circ}, 28.1^{\circ}, 30.1^{\circ}$, and $32.0^{\circ}$, which are in line with other studies findings [61,62]. The major peaks of zeolite at $22.4^{\circ}$ and $28.1^{\circ}$ have d-spacing values of $3.97 \AA$ and $3.17 \AA$, respectively. The XRD pattern of AS shows the characteristic main peaks at about $20.9^{\circ}, 26.7^{\circ}, 29.7^{\circ}, 42.5^{\circ}, 43.7^{\circ}, 45.8^{\circ}$, $48.4^{\circ}$, and $42.5^{\circ}$. The major peaks of ZAS are seen in the XRD chart at around $\sim 21.1^{\circ}$, $22.7^{\circ}, 26.8^{\circ}$, and $30.0^{\circ}$. The Scherrer equation was used to calculate the average crystallite sizes for Z, AS, and ZAS, which were found to be 29.6, 92.7, and $92.8 \mathrm{~nm}$, respectively, confirming their nanostructure nature.

The quantitative analysis of zeolite by XRF (X-ray fluorescence) shows that it consists of $\mathrm{K}_{2} \mathrm{O}$ with a weight $\%$ of $3.20 \%, \mathrm{CaO}$ with $3.50 \%, \mathrm{Na}_{2} \mathrm{O}$ with $0.78 \%, \mathrm{SiO}_{2}$ with $62.22 \%, \mathrm{MgO}$ with $0.59 \%, \mathrm{Fe}_{2} \mathrm{O}_{3}$ with $4.03 \%, \mathrm{TiO}_{2}$ with $0.34 \%, \mathrm{ZrO}_{2}$ with $0.11 \%$, $\mathrm{MnO}$ with $0.12 \%$ and very small traces of $\mathrm{Cl}, \mathrm{BaO}, \mathrm{ZnO}, \mathrm{SrO}, \mathrm{SO}_{3}$, and $\mathrm{P}_{2} \mathrm{O}_{5}$. For AS alga, flavonoids, alkaloids, steroids, saponins, and phenolic substances were all detected in preliminary qualitative tests. Thin-layer chromatography measurements revealed $R_{\mathrm{f}}$ values of $0.77 \pm 0.2$, $0.44 \pm 0.01,0.72 \pm 0.01,0.65 \pm 0.01,0.50 \pm 0.02$, respectively [34]. S.R. Sivakumar and K. Arunkumar's method of flame photometric sodium and potassium detection, as well as sulphate colorimetric estimation at $470 \mathrm{~nm}$, were used. This resulted in sulphate of $88.50 \mathrm{mg} / \mathrm{g}$ and $\mathrm{Na}^{+} / \mathrm{K}^{+}$of 0.52 [63]. 


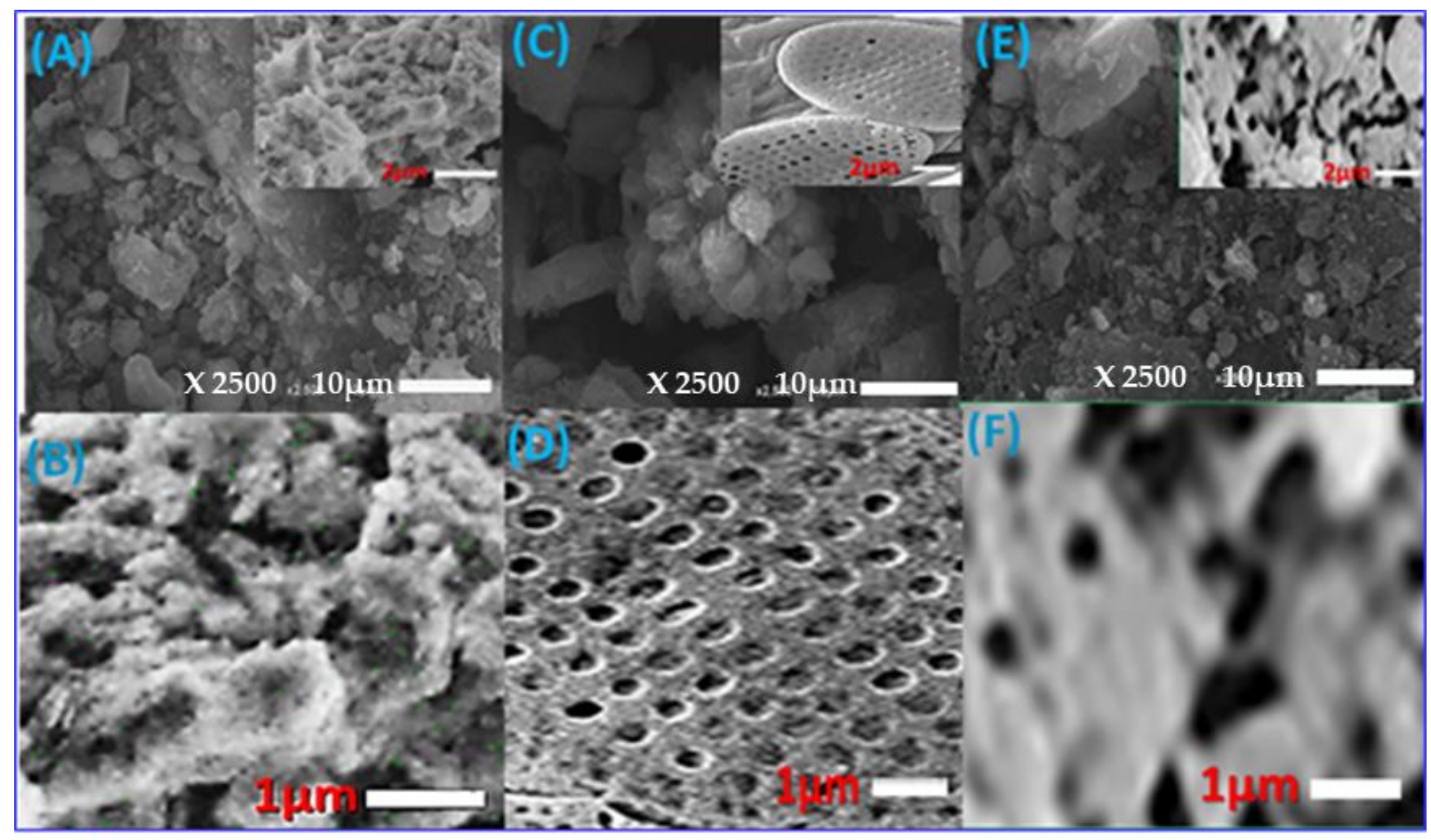

Figure 1. SEM micrographs of (A,B) Z, (C,D) AS, and (E,F) ZAS adsorbents.
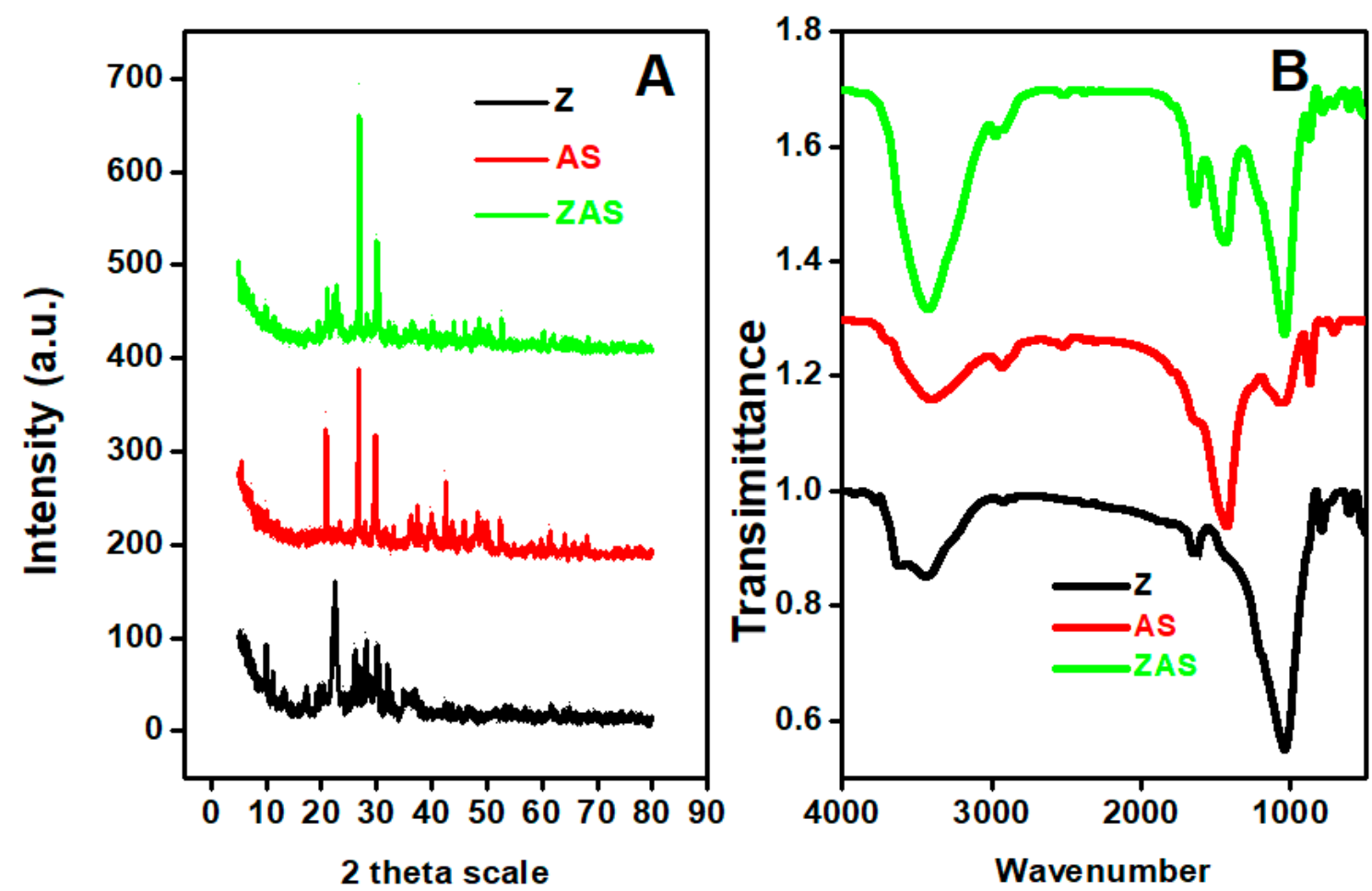

Figure 2. (A) XRD and (B) FTIR charts of Z, AS, and ZAS adsorbents.

\subsubsection{FT-IR Analysis}

FT-IR charts of Z, AS, and ZAS adsorbent are shown in Figure $2 b$. The spectrum showed the broadband of $(\mathrm{OH})$ groups, where the bands at 3452,3432 , and $3442 \mathrm{~cm}^{-1}$ are characteristics of the inner $\mathrm{OH}$ stretching hydroxyl group [64,65]. In the case of zeolite, 
the band at $1029 \mathrm{~cm}^{-1}$ corresponds to the $\mathrm{Si}-\mathrm{O}$ vibration mode, which is displaced to $1039 \mathrm{~cm}^{-1}$ for ZAS [66]. The 603 and $919 \mathrm{~cm}^{-1}$ bands are associated with Si-O-Al and octahedral aluminum (Al-OH), respectively [67]. The band at $464 \mathrm{~cm}^{-1}$ is associated with the $\mathrm{Si}-\mathrm{O}-\mathrm{Si}$ bending of zeolite, which is shifted to $\sim 460 \mathrm{~cm}^{-1}$ for ZAS [67]. The bands that appeared in the region from 400 to $800 \mathrm{~cm}^{-1}$ are related to the metal oxides [68].

In the FT-IR spectrum of AS algae, the band at $3786 \mathrm{~cm}^{-1}$ is ascribed to the amine group (-NH) stretching, while the band at $3431 \mathrm{~cm}^{-1}$ is related to the hydroxyl group (-OH) of phenolic groups. The band at $2916 \mathrm{~cm}^{-1}$ was allocated to the alkyl groups $(-\mathrm{CH})$ stretching, while the band at $1627 \mathrm{~cm}^{-1}$ is corresponding to the $-\mathrm{C}=\mathrm{O}$ vibration. The mode at $\sim 1426 \mathrm{~cm}^{-1}$ is ascribed to the $\mathrm{C}-\mathrm{H}$ vibration [69]. The bands located around $1020 \mathrm{~cm}^{-1}$ refer to the sulfate group or the C-O bond [70]. Bands around $3300-3500 \mathrm{~cm}^{-1}$ are characteristic of the $\mathrm{N}-\mathrm{H}$ stretching mode of amines. The mode at $2916 \mathrm{~cm}^{-1}$ refers to the $\mathrm{O}-\mathrm{H}$ stretching mode of a carboxylic group [71]. In addition to the existence of AS bands, zeolite bands can be seen in the FT-IR spectrum of ZAS, indicating that zeolite was impregnated with AS to produce the ZAS composite. The band located at $2915 \mathrm{~cm}^{-1}$, stretching vibration of $\mathrm{CH}_{2}$ groups, in the ZAS composite (Figure $2 \mathrm{~b}$ ) suggests the interaction between alga function groups and active molecules on the surface of zeolite because it is not one of the characteristic bands of zeolite in the IR spectra. Absorption bands of ZAS composite were observed at around $3300-3600$ and $1000-1660 \mathrm{~cm}^{-1}$, and the intensities of the AS characteristic peaks notably increased with the incorporation of zeolite. Both band shift and band disappearance are in line with data obtained from other characterization techniques, which confirms the formation of the new ZAS composite. All bands shifts and assignments are summarized in Table S2.

\subsection{Factors Influencing the Adsorption Process}

\subsubsection{Influence of Starting CR Concentration}

The amount of CR removed by adsorption is highly dependent on the starting CR concentrations. The variations in the removal\% and the amount of $C R$ adsorbed using $\mathrm{Z}, \mathrm{AS}$, and ZAS adsorbents at different initial concentrations with time are illustrated in Figure $3 \mathrm{a}-\mathrm{f}$. The adsorption capacities and dye removal percentages are typically quite high during the initial stage of the adsorption process. Their growth is then slowed until the equilibrium state is reached. The presence of a large number of exposed active adsorption sites on the adsorbent surface may account for the high removal rate early in the reaction. The active sites become fully occupied by the CR molecules as the contact period between adsorbent and adsorbate increases. Because of the repulsive forces that exist between the adsorbed CR molecules on the adsorbent surfaces and those in the bulk liquid phase, the adsorption process is highly expected to follow the Langmuir mechanistic [72]. Hence, as the starting CR concentration increases, so does the proportion of CR eliminated. On the other hand, the amount of dye adsorbed by the adsorbent increases when the starting CR concentration rises, possibly due to increased mass transfer driving forces at higher starting $C R$ concentrations. At all concentrations, the ZAS nanocomposite showed better performance for $\mathrm{CR}$ adsorption, and the $\mathrm{CR}$ elimination percent was in the sequence ZAS > AS > Z. The presence of phytochemical constituents such as phenols, alkaloids, saponins, flavonoids, and steroids, which contain several active functional groups such as carboxylic, hydroxyl, amino, carbonyl, phosphates, and sulfonic, may account for the higher removal percent of adsorbents containing AS species, as well as the high porosity and surface area of the AS and ZAS samples as seen in SEM images and PET measurements $[39,40]$. 


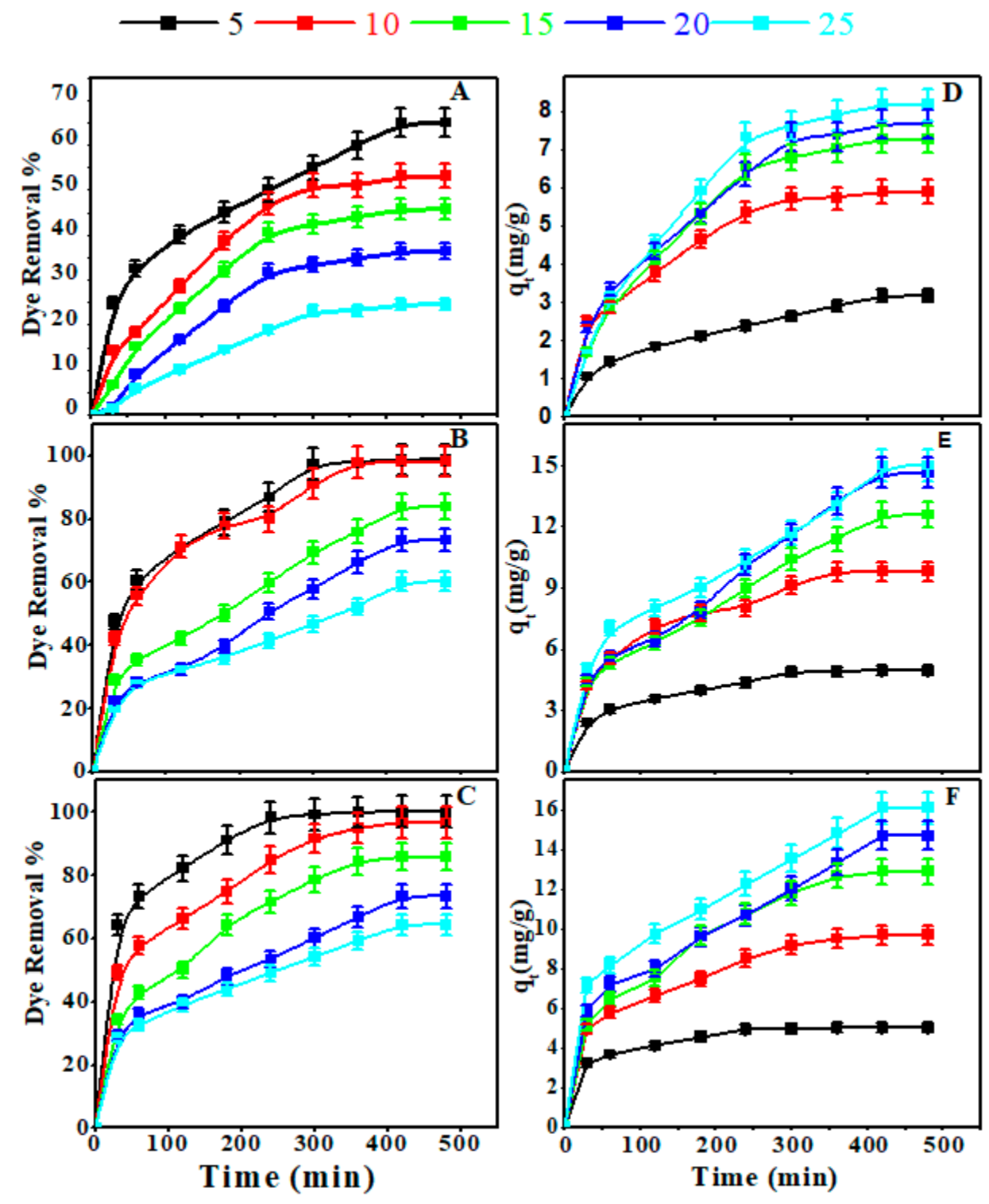

Figure 3. Effect of $C R$ dye concentration and contact time on the removal\% and the amount of $C R$ dye adsorbed at $25^{\circ} \mathrm{C}$ and $\mathrm{pH} 7$ by $20 \mathrm{mg}$ of $(\mathbf{A}, \mathbf{D}) \mathrm{Z},(\mathbf{B}, \mathbf{E}) \mathrm{AS}$, and $(\mathbf{C}, \mathbf{F}) \mathrm{ZAS}$.

\subsubsection{Influence of Adsorbent Dosage}

The influence of adsorbent dose on CR removal percent is evaluated concerning adsorption cost at the optimal adsorbent dosage for best efficiency. Figure 4a depicts this graphically, with adsorbent dosages ranging from 0.01 to $0.05 \mathrm{~g}$. Figure $4 \mathrm{a}$ shows that increasing the adsorbent dose from 0.01 to $0.05 \mathrm{~g}$ enhances the dye removal percent for all adsorbents; it rose from 46.2 to 64.6 percent for $Z$ adsorbent, from 68.9 to 98.8 percent for AS adsorbent, and from 88.1 to $99.8 \%$ percent for ZAS adsorbent. This observation could be attributed to an increase in the frequency of active sites caused by increasing the adsorbent bulk $[3,4,72]$. It was observed that a large jump in removal\% takes place by increasing the adsorbent dose from 0.01 to $0.02 \mathrm{~g}$ in the case of ZAS and from 0.01 to $0.03 \mathrm{~g}$ in the case of Z. By increasing the adsorbent dose over $0.02 \mathrm{~g}$ and $0.03 \mathrm{~g}$ in the case of ZAS and Z, respectively, the change in the removal\% became slightly small. This could be related to the adsorbent's screen effect, which occurs at higher adsorbent dosages [73]. Dense layers arise on adsorbent surfaces as a result of the accumulation of adsorbent molecules and the reduction in the space between them. The active sites were hidden from CR molecules by the formed dense layers. Furthermore, $\mathrm{Z}$ and ZAS overlapping resulted in a competition between $\mathrm{CR}$ molecules for restricted available binding sites. Agglomeration or aggregation 
at higher $\mathrm{Z}$ and ZAS dosages lengthen the diffusion paths for CR adsorption, lowering the adsorption rate [51,74-76].
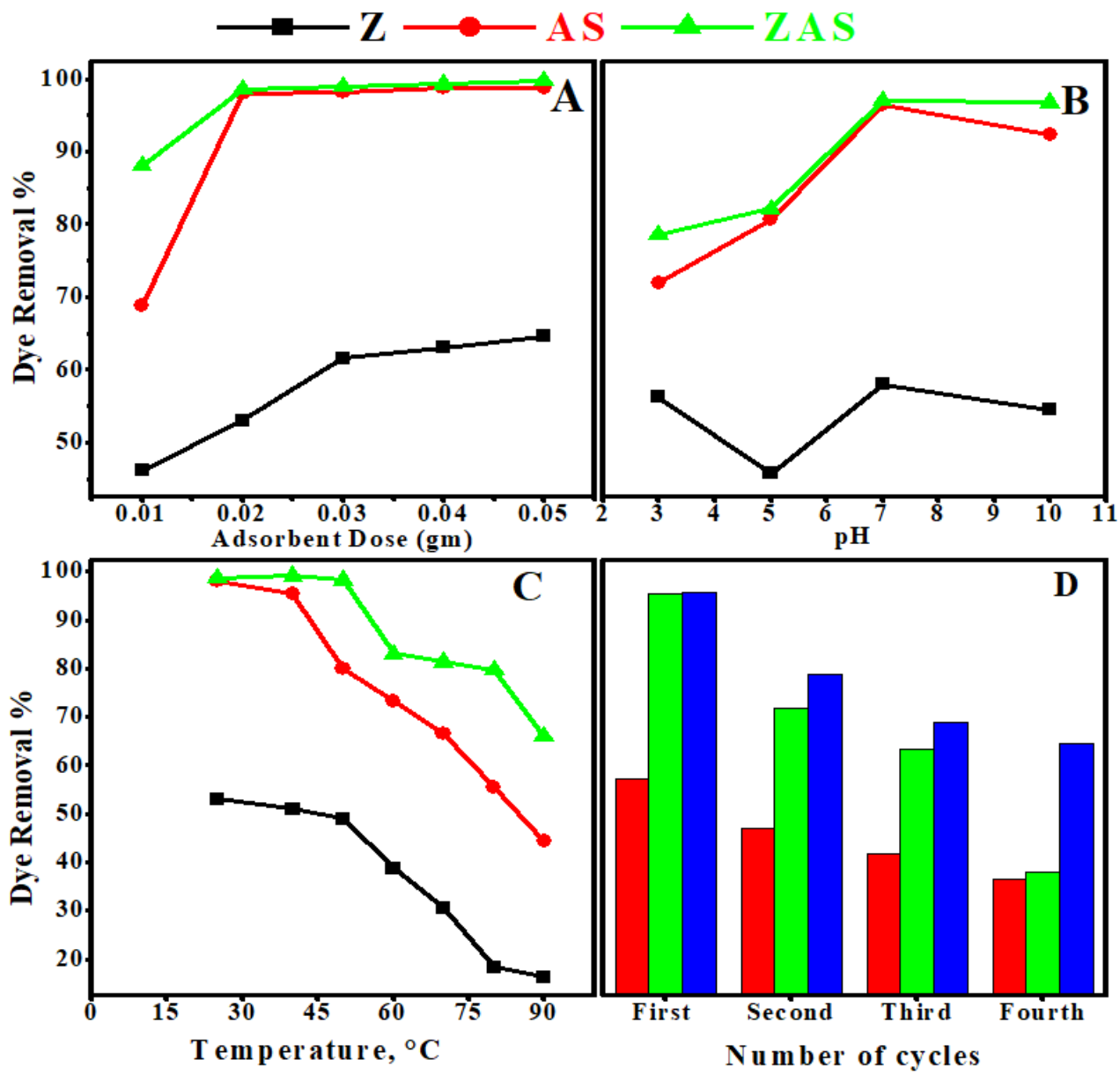

Figure 4. Effect of (A) adsorbent dose, (B) initial $\mathrm{pH}$ of the solution, $(\mathbf{C})$ adsorption temperature, and (D) reusability test on the removal\% of $20 \mathrm{~mL} \mathrm{CR}$ solution of $10 \mathrm{mg} / \mathrm{L} \mathrm{by} \mathrm{Z}$, AS, and ZAS.

\subsubsection{Influence of $\mathrm{pH}$}

$\mathrm{pH}$ is regarded as one of the most important elements regulating adsorbent dye removal capability in wastewater. The $\mathrm{pH}$ of the solution influences adsorption efficacy because changes in $\mathrm{pH}$ alter the degree of ionization of the adsorptive molecules as well as the surface properties of the adsorbent. Its effect on the adsorbent's CR removal effectiveness was investigated between $\mathrm{pH} 3$ and $\mathrm{pH} 10$, as shown in Figure $4 \mathrm{~b}$. For $20 \mathrm{~mL}$ of $10 \mathrm{mg} / \mathrm{L} \mathrm{CR}$ solution with a $\mathrm{Z}$ dose of $0.02 \mathrm{~g}$, the $\mathrm{Z}$ adsorbent displays removal percentages of $\sim 51.02 \%, 38.78 \%, 53.06 \%$, and $48.98 \%$ at $\mathrm{pH}$ values of $3,5,7$, and 10 , respectively. The AS adsorbent shows removal percentages $69.39,79.54,98.00$, and $93.08 \%$, while ZAS adsorbent represents removal percentages $77.08,81.25,98.61$, and $98.33 \%$ at $\mathrm{pH}$ values of $3,5,7$, and 10 , respectively, at the same previously mentioned conditions. As shown in Figure $4 \mathrm{~b}$, when the $\mathrm{pH}$ of the solution is 7, the adsorption capacities of CR on Z, AS, and ZAS reached their maxima. This may be because the interaction between adsorbent and CR is more pronounced than the interaction with $\mathrm{OH}^{-}$ions in the solution [77]. At very low $\mathrm{pH}$ values, the positive charge on the solution interface grows, and the Z, AS, and ZAS surfaces seem positively charged. However, due to protonation, CR in the solution tends to be neutral. This scenario results in a decrease in anionic CR adsorption, as shown at pH 5 [78]. At high $\mathrm{pH}$ values, on the other hand, the positive charge on the solution interface decreases, and $\mathrm{CR}$ becomes negatively charged with $\mathrm{OH}^{-}$ions. As a result, positively charged $\mathrm{Z}, \mathrm{AS}$, 
and ZAS interact competitively with negatively charged $\mathrm{CR}$ dyes or $\mathrm{OH}$ - ions. As a result, when $\mathrm{pH}$ exceeds 7, CR adsorption decreases once more [79].

\subsubsection{Influence of Temperature}

The effect of temperature is an important physicochemical factor, as it causes variation in the adsorption capacities of the adsorbents [80]. The adsorption tests were conducted at $25,40,50,60,70,80$, and $90^{\circ} \mathrm{C}$, and the results are shown in Figure 4c. Where a decrease in CR removal\% occurs with increasing temperature. This may be owed to the desorption manners resulted from the breakdown of adsorption forces that were liable for the adsorption of dye molecules on the adsorbent surface [81], which might be due to damaging of active sites, the weakening of adsorptive forces between active binding sites of the adsorbent and the adsorbate species [3,82,83]. As a result, the optimal temperature for CR adsorption is between $25^{\circ} \mathrm{C}$ and $45^{\circ} \mathrm{C}$, especially for ZAS adsorbents. The drop in CR removal percentage as temperature rises indicates that adsorption is an exothermic process.

\subsubsection{Reusability Test}

Z, AS, and ZAS reusability for the elimination of CR was repeated for four cycles using the same adsorbent dosage (Figure $4 \mathrm{~d}$ ). The data illustrated that; the removal\% of all used adsorbents varied throughout the four adsorption cycles. For $\mathrm{Z}$ adsorbent, the recorded dye removal\% was $53.1 \%$ at the first cycle, $40.8 \%$ at the second cycle, $34.7 \%$ at the third cycle, and $28.6 \%$ at the fourth cycle. For AS adsorbent, the dye removal $\%$ decreased from $98.0 \%$ at the first cycle to $30.0 \%$ at the fourth cycle. For the ZAS nanoadsorbent, the dye removal\% decreased from $98.6 \%$ at the first cycle to $61.7 \%$ at the fourth cycle. The agglomeration of CR molecules on the surfaces of Z, AS, and ZAS adsorbents conceal the adsorbent surfaces and pores from the dissolved CR molecules, resulting in a reduction in adsorption capacity [84].

\subsection{Adsorption Isotherms}

Figure 5a shows qe vs. Ce curves for Z, AS, and ZAs adsorbents to demonstrate the property of equilibrium adsorption. For the Langmuir, Freundlich, and Tempkin isotherms, these equilibrium curves were fitted. The statistical significance of correlation coefficient $\left(\mathrm{R}^{2}\right)$ for linear fitting of $\mathrm{Ce} /$ qe vs. Ce, $\log (\mathrm{qe})$ vs. $\log (\mathrm{Ce})$, and qe vs. $\operatorname{Ln}(\mathrm{Ce})$ plots, respectively. The presented values of $Q_{0}, K_{L}, K_{F}, n, K_{T}, B$, and $R^{2}$ in Table 1 are computed from the linear fitting of the plots in Figure $5 \mathrm{~b}-\mathrm{d}$. The data in Table 1 reveal that CR adsorption on Z, AS, and ZAS adsorbents follow the Langmuir isotherm model with the best $\mathrm{R}^{2}$ value. Therefore, the elimination of the dye occurs at the active sites of the Z, AS, and ZAS adsorbents on a single surface layer (monolayer adsorption), and the adsorbed CR molecules do not react with each other. At $25^{\circ} \mathrm{C}$, the Langmuir isotherms of $Z$, AS, and ZAS have $\mathrm{R}^{2}$ values of $0.9795,0.9985$, and 0.9952 , respectively. The value of $\mathrm{R}_{\mathrm{L}}$ is less than one, indicating that CR adsorption in the studied case is valuable [85]. The maximum amount of CR adsorbed on the surface of Z, AS, and ZAS, according to the Langmuir isotherm model, was expected to be $9.25,15.38$, and $16.39 \mathrm{mg} / \mathrm{g}$. 
- Z A AS ZAS
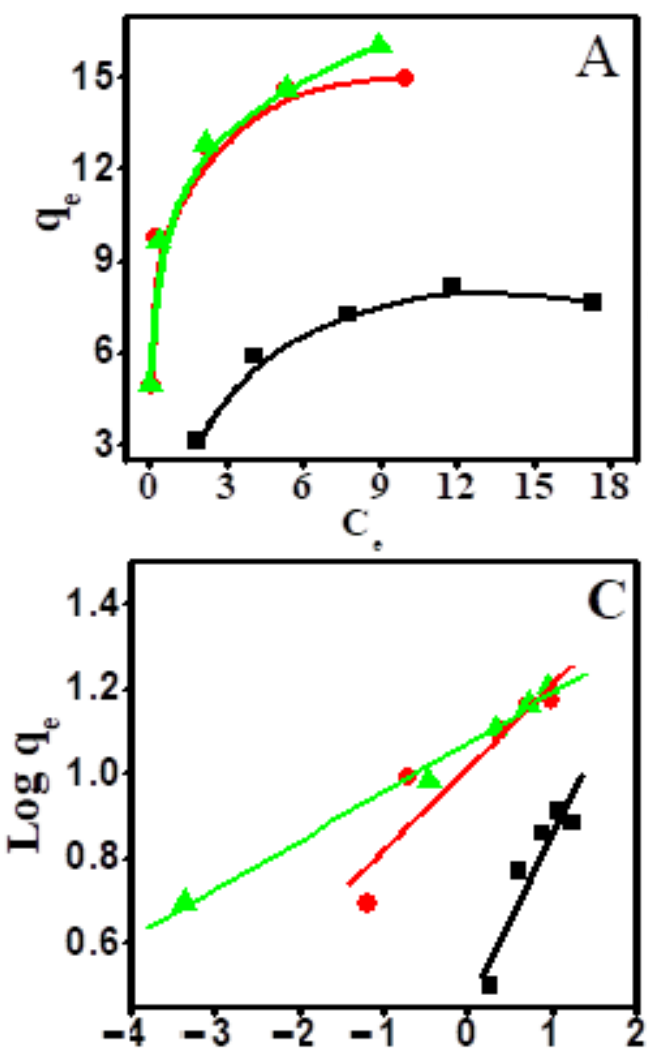

$\log C_{\text {s }}$
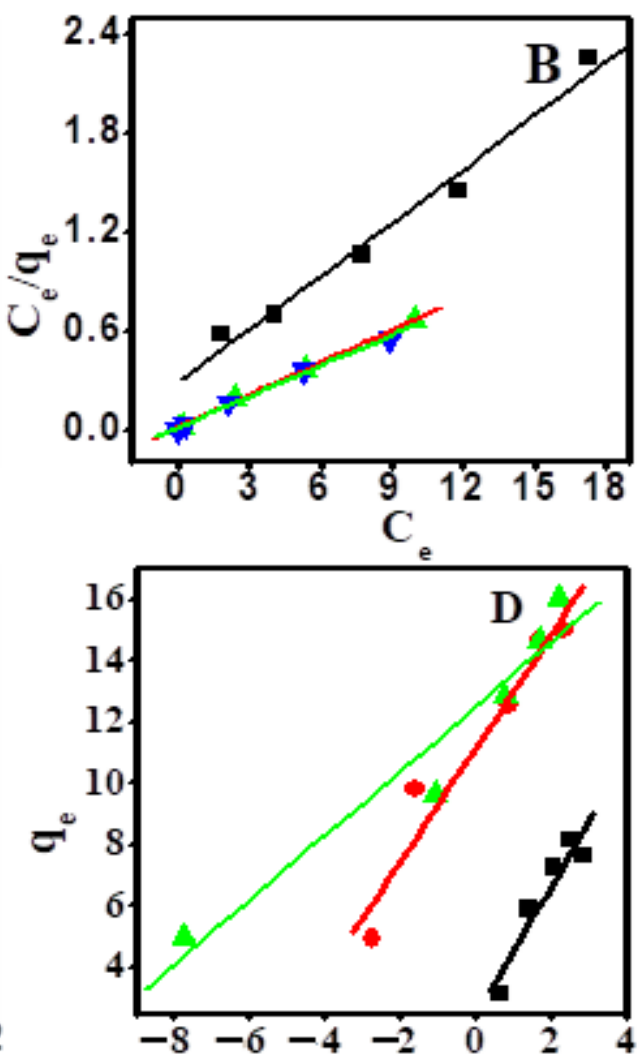

Ln C,

Figure 5. Plots of (A) Ce versus Qe, (B) Langmuir, (C) Freundlich, and (D) Temkin adsorption isotherms for the adsorption of $\mathrm{CR}$ dye by $20 \mathrm{mg}$ of $\mathrm{Z}, \mathrm{AS}$, and $\mathrm{ZAS}$ at $25^{\circ} \mathrm{C}$ and initial $\mathrm{pH} 7$.

Table 1. Isotherm parameters for CR adsorption on Z, AS, and ZAS.

\begin{tabular}{|c|c|c|c|c|c|}
\hline \multicolumn{6}{|c|}{ Langmuir Isotherm } \\
\hline $\begin{array}{l}\text { Constant } \\
\text { Adsorbent }\end{array}$ & $Q_{o}(\mathrm{mg} / \mathrm{g})$ & $\mathrm{K}_{\mathrm{L}}(\mathrm{L} / \mathrm{mg})$ & $\mathbf{R}_{\mathbf{L}}$ & & $\mathbf{R}^{2}$ \\
\hline ZAS & 16.39 & 3.59 & 0.9951 & & 0.011 \\
\hline AS & 15.38 & 4.29 & 0.9984 & & 0.009 \\
\hline $\mathbf{Z}$ & 9.25 & 0.38 & 0.094 & & 0.9794 \\
\hline \multicolumn{6}{|c|}{ Freundlich Isotherm } \\
\hline $\begin{array}{l}\text { Constant } \\
\text { Adsorbent }\end{array}$ & $1 / n$ & $\mathbf{K}_{\mathrm{f}}$ & & $\mathbf{R}^{2}$ & \\
\hline ZAS & 0.116 & 11.40 & & 0.9890 & \\
\hline AS & 0.196 & 10.34 & & 0.8601 & \\
\hline $\mathbf{Z}$ & 0.404 & 2.85 & & 0.8569 & \\
\hline \multicolumn{6}{|c|}{ Temkin Isotherm } \\
\hline $\begin{array}{l}\text { Constant } \\
\text { Adsorbent }\end{array}$ & $\mathrm{B}(\mathrm{J} / \mathrm{mol})$ & $\mathrm{K}_{\mathrm{T}}(\mathrm{L} / \mathrm{mole})$ & & $\mathbf{R}^{2}$ & \\
\hline ZAS & 1.0571 & 140,930 & & 0.9890 & \\
\hline AS & 1.856 & 416.5 & & 0.8601 & \\
\hline $\mathbf{Z}$ & 2.1487 & 2.85 & & 0.8569 & \\
\hline
\end{tabular}




\subsection{Adsorption Kinetics and Sorption Mechanism}

To study the most suitable kinetic model, the adsorption process of $C R$ on $Z$, AS, and ZAS was followed at varying initial dye concentrations. Ln $\left(q_{e}-q_{t}\right) v s . t, t / q_{t} v s . t$, and $q_{t} v s . \ln (t)$ are used to illustrate the linear forms of the first-order, second-order, and Elovich kinetic models, Figure 6. The kinetic and statistical parameters, $\mathrm{k}_{1}, \mathrm{k}_{2}, \mathrm{q}_{\mathrm{e}}$, $\beta, \alpha$, and $R^{2}$, are obtained and depicted in Table 2 . The linear regression data in Table 2 show that CR adsorption onto Z, AS and ZAS is well fitted by second-order kinetics for the studied concentration range and models. At dye concentrations of 5, 10, 15, 20, and $25 \mathrm{ppm}, \mathrm{R}^{2}$ values for the second-order fit for ZAS are $0.9989,0.9922,0.9857,0.9562$, 0.9712 , respectively. These $R^{2}$ values are higher than those found for the Elovich and firstorder models. Moreover, the behavior of AS adsorbent followed showed high R2 values, especially at low $\mathrm{CR}$ concentrations. This was further reinforced by the good approximation between the estimated $\mathrm{q}_{\mathrm{e}}$ and experimental $\mathrm{q}_{\exp }$. Two phases are involved in the pseudosecond-order adsorption mechanism. External diffusion refers to the transport of $C R$ molecules from all sides to the outside surfaces of $Z$ and AS. The CR molecules then adsorb and attach to the surfaces of $Z, A S$, and ZAS in a second stage.
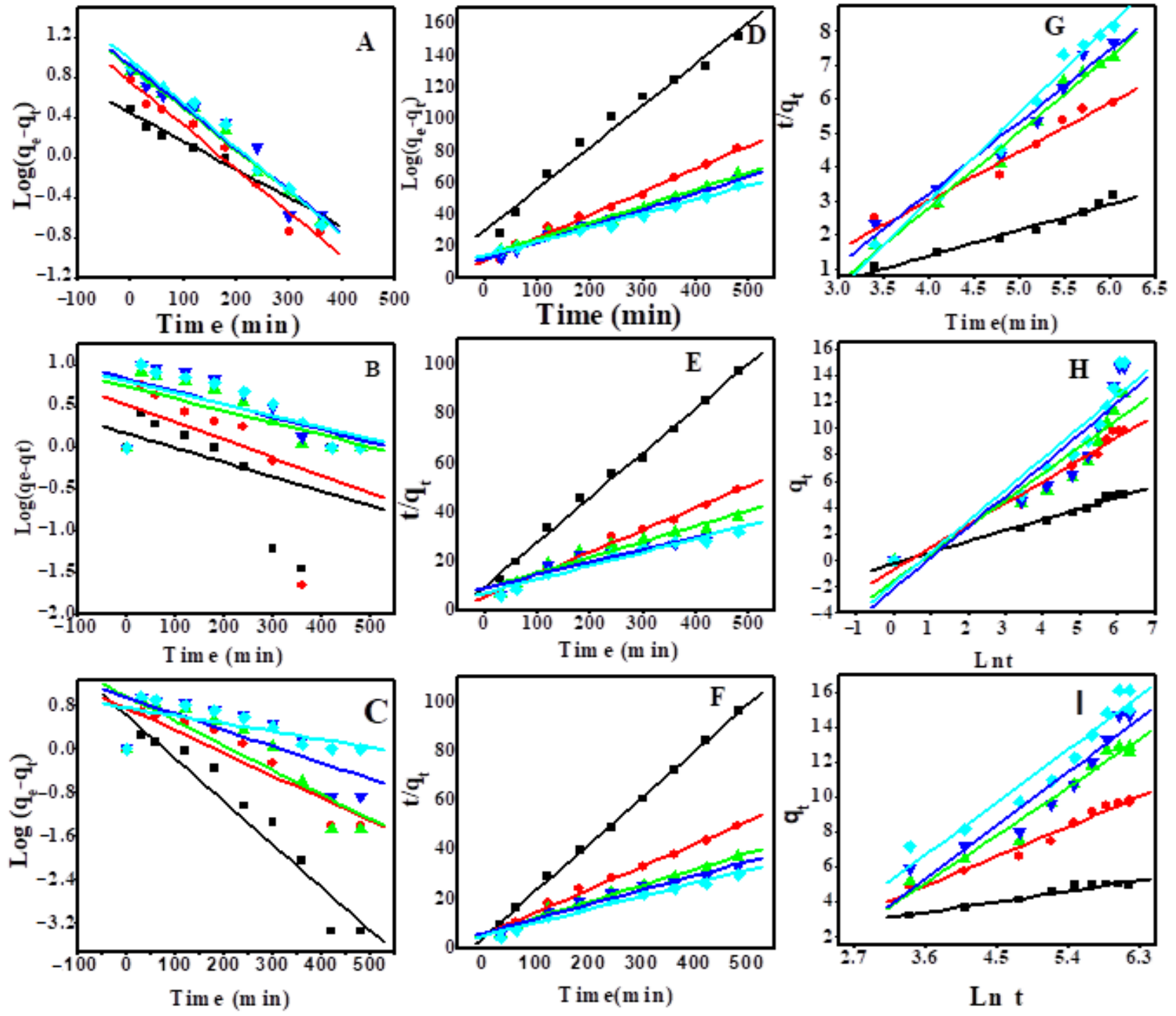

Figure 6. (A-C) pseudo-first-order, (D-F) pseudo-second-order, and (G-I) Elovich sorption kinetics of CR dye at $25^{\circ} \mathrm{C}$ and $\mathrm{pH} 7$ by $20 \mathrm{mg}$ of $\mathrm{Z}, \mathrm{AS}$, and ZAS, respectively. 
Table 2. Parameters of the kinetic models for CR dye adsorption on $\mathrm{Z}, \mathrm{AS}$, and ZAS at $25^{\circ} \mathrm{C}$.

\begin{tabular}{|c|c|c|c|c|c|c|c|c|c|c|c|c|c|c|}
\hline \multirow[b]{2}{*}{ Adsorbent } & \multirow{2}{*}{$\begin{array}{l}\text { Conc, } \\
\text { Ppm }\end{array}$} & \multicolumn{4}{|c|}{ First-Order } & \multicolumn{3}{|c|}{ Second-Order } & \multicolumn{3}{|c|}{ Elovich Kinetic Model } & \multicolumn{3}{|c|}{$\begin{array}{c}\text { Intraparticle Diffusion } \\
\text { Model }\end{array}$} \\
\hline & & $\underset{\exp }{\mathrm{q}_{\mathrm{e}}}$ & $\mathrm{q}_{\mathrm{e} \text { calc. }}$ & $\mathbf{k}_{1}$ & $\mathbf{R}^{2}$ & qe calc. & $\mathbf{k}_{2}$ & $\mathbf{R}^{2}$ & $\begin{array}{c}\beta \\
(\mathrm{g} / \mathrm{mg})\end{array}$ & $\begin{array}{c}\alpha \\
(\mathrm{mg} / \mathrm{min})\end{array}$ & $\mathbf{R}^{2}$ & $\mathbf{I}$ & $\begin{array}{c}\mathrm{k}_{3} \\
(\mathrm{mg} / \mathrm{g} . \\
\left.\min ^{1 / 2}\right)\end{array}$ & $\mathbf{R}^{2}$ \\
\hline \multirow{5}{*}{$\mathbf{Z}$} & 5 & 3.10 & 2.75 & 0.0028 & 0.9603 & 3.82 & 0.00228 & 0.9751 & 1.3158 & 0.0844 & 0.9597 & 0.167 & 0.146 & 0.9909 \\
\hline & 10 & 5.90 & 5.75 & 0.0043 & 0.9682 & 6.94 & 0.00189 & 0.9918 & 0.7143 & 0.2035 & 0.9575 & 0.510 & 0.293 & 0.9661 \\
\hline & 15 & 7.25 & 7.95 & 0.0041 & 0.9845 & 9.70 & 0.00073 & 0.9917 & 0.4546 & 0.1375 & 0.9835 & -0.033 & 0.381 & 0.9821 \\
\hline & 20 & 7.60 & 8.50 & 0.0042 & 0.9352 & 9.80 & 0.00087 & 0.9854 & 0.4762 & 0.1765 & 0.9630 & 0.168 & 0.389 & 0.9898 \\
\hline & 25 & 8.10 & 9.50 & 0.0043 & 0.9798 & 11.36 & 0.00055 & 0.9890 & 0.3846 & 0.1510 & 0.9835 & -0.175 & 0.435 & 0.9805 \\
\hline \multirow{5}{*}{ AS } & 5 & 4.93 & 1.49 & 0.0039 & 0.2210 & 5.53 & 0.00329 & 0.9945 & 1.1976 & 0.6439 & 0.9830 & 0.893 & 0.212 & 0.9160 \\
\hline & 10 & 9.80 & 3.27 & 0.0048 & 0.2790 & 11.13 & 0.00138 & 0.9920 & 0.6050 & 1.1394 & 0.9730 & 1.490 & 0.427 & 0.9370 \\
\hline & 15 & 12.58 & 5.42 & 0.0033 & 0.3980 & 15.86 & 0.00044 & 0.9398 & 0.4936 & 0.9474 & 0.8730 & 0.467 & 0.567 & 0.9870 \\
\hline & 20 & 14.65 & 6.79 & 0.0035 & 0.3660 & 19.68 & 0.00027 & 0.8960 & 0.4255 & 0.9534 & 0.8271 & 0.0002 & 0.673 & 0.9810 \\
\hline & 25 & 15.00 & 6.31 & 0.0032 & 0.3310 & 18.13 & 0.00042 & 0.9362 & 0.4237 & 1.1779 & 0.8860 & 0.793 & 0.653 & 0.9800 \\
\hline \multirow{5}{*}{ ZAS } & 5 & 4.99 & 4.08 & 0.0182 & 0.9201 & 5.31 & 0.00738 & 0.9989 & 1.4201 & 2.2864 & 0.9680 & 1.471 & 0.195 & 0.7910 \\
\hline & 10 & 9.66 & 5.56 & 0.0094 & 0.7940 & 10.85 & 0.00155 & 0.9922 & 0.5309 & 0.6954 & 0.9680 & 1.727 & 0.409 & 0.9220 \\
\hline & 15 & 12.85 & 9.10 & 0.0104 & 0.7260 & 15.35 & 0.00071 & 0.9857 & 0.3248 & 0.4324 & 0.9630 & 1.275 & 0.581 & 0.9698 \\
\hline & 20 & 14.66 & 8.67 & 0.0069 & 0.5395 & 16.79 & 0.00056 & 0.9562 & 0.3037 & 0.4656 & 0.9130 & 1.251 & 0.634 & 0.9750 \\
\hline & 25 & 16.07 & 5.73 & 0.0034 & 0.3867 & 18.56 & 0.00059 & 0.9712 & 0.2943 & 0.6577 & 0.9300 & 1.865 & 0.683 & 0.9650 \\
\hline
\end{tabular}

To understand the mechanism and rate-controlling steps affecting adsorption kinetics. The experimental results were fitted for Weber's intra-particle diffusion. A straight line in the chart of $q_{t}$ versus $t^{1 / 2}$ (Figure 7) proposes the applicability of the intra-particle diffusion model. $K_{3}$ and I can be determined from the slope and intercept of the plot, respectively, and the results are provided in Table 2. The value of intercept I is not zero, demonstrating that the intra-particle diffusion model may not be the sole rate-controlling factor in determining the kinetics of the adsorption process [86]. The intercept in Figure 7 reflects the boundary layer effect. The larger the intercept, the greater the contribution of surface adsorption in the rate control step [86].

\subsection{Computational Analysis}

Figure 8 reveals the minimum configurations obtained due to $C R$ adsorption on clinoptilolite surface at three different sizes. The main target from MC simulation was to establish to what limit different planes and sizes of clinoptilolite will affect $\mathrm{CR}$ adsorption. Table 3 lists the adsorption energies of each zeolite clinoptilolite-Congo red system. Figure S3 (Supplementary Materials) shows the entire simple box system for adsorption configurations of Congo red on the clinoptilolite surface. Figure 8a-c illustrates simple snapshots of CR adsorption on the clinoptilolite's surface (a dry system with no solvents containing 3, 5, and $7 \mathrm{~nm}$ simple box systems). Different $\mathrm{H}^{-}$bond (HB) donor/acceptor regions were found clearly on CR molecules. Therefore, a number of HBs were formed between $\mathrm{N}$ and $\mathrm{O}$ atoms of the CR molecule and surface of clinoptilolite. Different possibilities were revealed in Figure 8, showing HBs and intramolecular HBs formed in a definite system ( $3 \mathrm{~nm}$ simple box); these bonds were lost in other systems ( 5 and $7 \mathrm{~nm}$ simple box). Table 3 summarizes the energy of adsorption $\left(\Delta \mathrm{E}_{\mathrm{ads}}\right)$, energy of interaction $\left(\mathrm{E}_{\mathrm{int}}\right)$, and energy of deformation $\left(\mathrm{E}_{\mathrm{def}}\right)$ besides substrate-adsorbate configurations $\left(\mathrm{dE}_{\mathrm{ads}} / \mathrm{dN}_{\mathrm{i}}\right)$, after removing one of the adsorbate components. Negative values of energy of adsorption for all configurations were obtained, indicating that the adsorption of the Congo red molecule on the surface of clinoptilolite is exothermic, energetically advantageous, and spontaneous due to the presence of intermolecular physical bindings. Moreover, increasing the size of the zeolite clinoptilolite has a considerable impact on the adsorption energy of all configurations, as adsorption energies decrease as the size of a simple box increases. Both HBs and intramolecular HBs between $\mathrm{O}$ and $\mathrm{N}$ of $\mathrm{CR}$ molecules and $\mathrm{OH} / \mathrm{H}$ atoms of the clinoptilolite are weaker in the 5 and $7 \mathrm{~nm}$ simple boxes than that in the case of $3 \mathrm{~nm}$ simple box. This resulted in an 
obvious reduction in $\Delta \mathrm{E}_{\text {ads }}$ values for 5 and $7 \mathrm{~nm}$ while larger values for $3 \mathrm{~nm}$ simple box systems, as shown in Table 3.
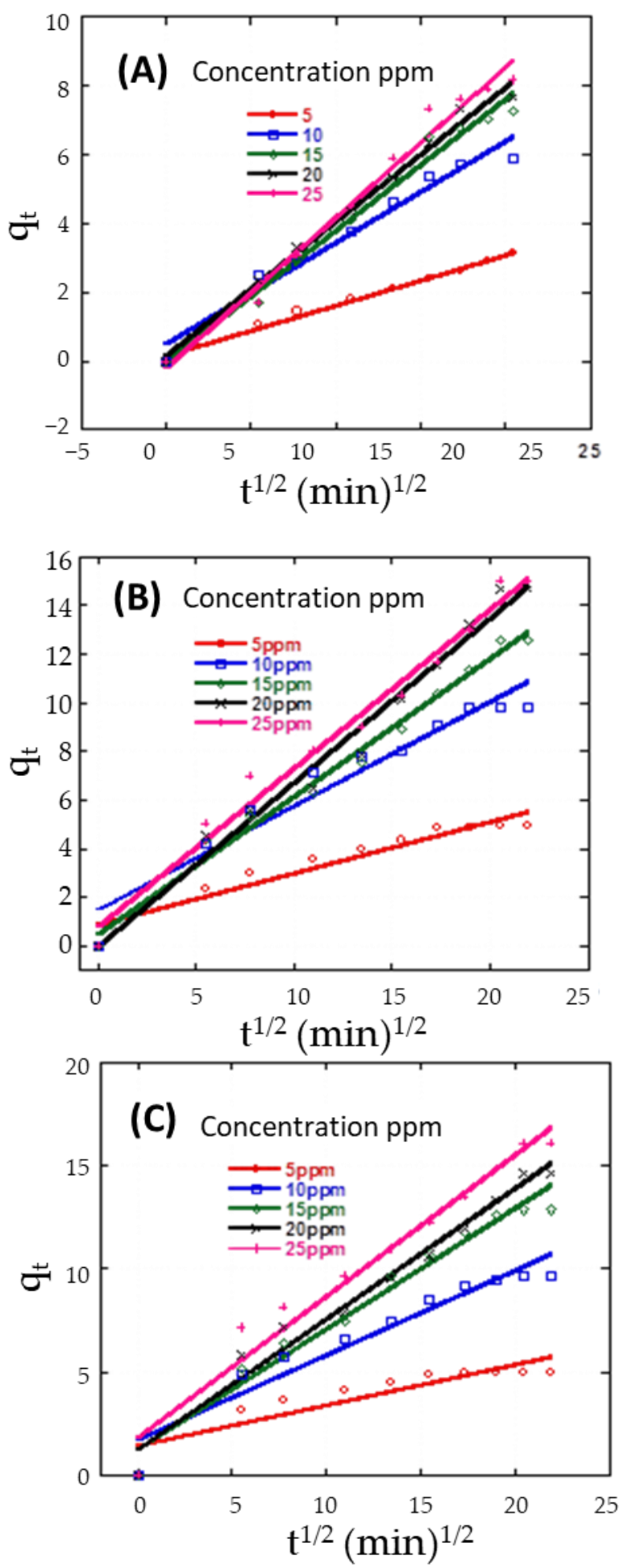

Figure 7. Intra-particle sorption kinetics of $\mathrm{CR}$ dye at $25^{\circ} \mathrm{C}$ and $\mathrm{pH} 7$ by $20 \mathrm{mg}$ of (A) $\mathrm{Z}$, (B) AS, and (C) ZAS. 


\section{(A) $3 \mathrm{~nm}$ Simple box system}

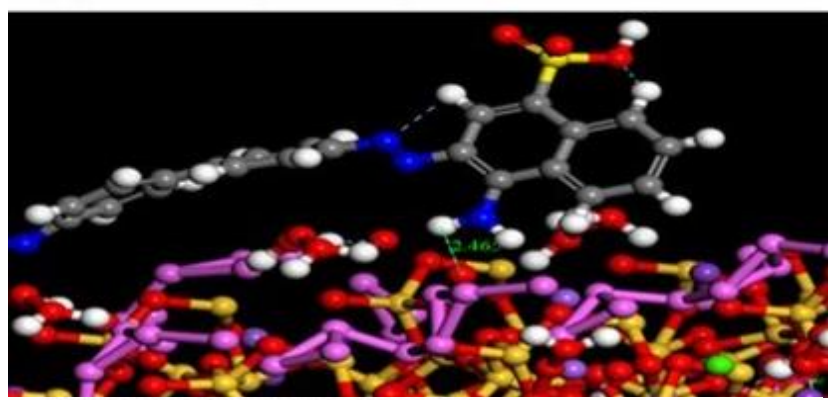

(B) $5 \mathrm{~nm}$ Simple box system

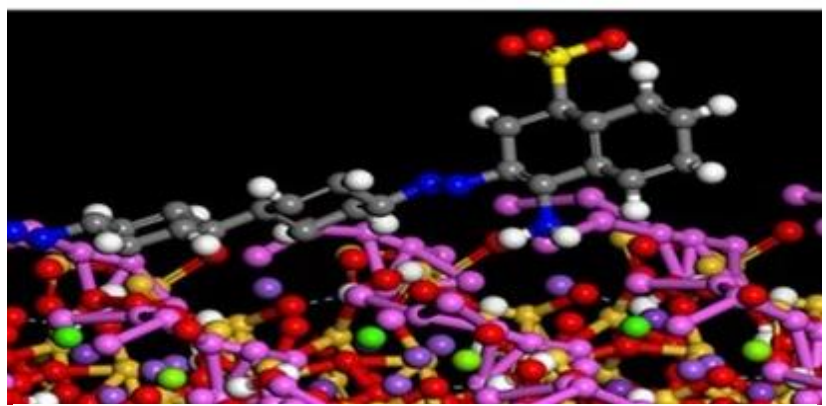

(C) $7 \mathrm{~nm}$ Simple box system

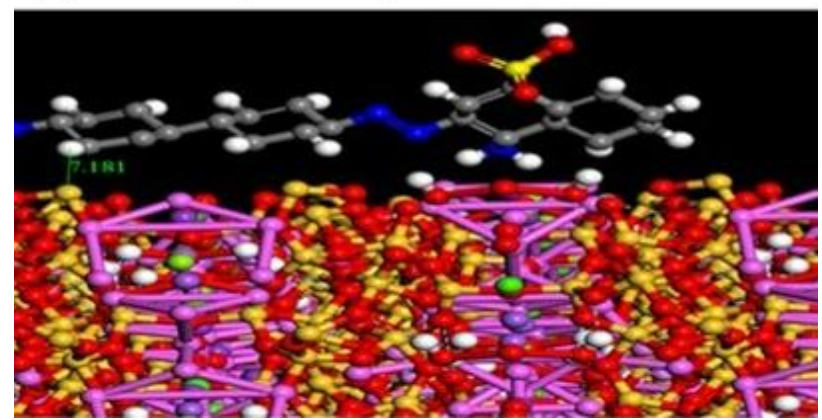

Figure 8. Snapshots for the adsorption configurations of CR/zeolite clinoptilolite of 3, 5, and $7 \mathrm{~nm}$ simple box systems, the bond length is in Angstroms.

Table 3. Energy of adsorption for adsorption configurations of Congo red on the surface of clinoptilolite with 3, 5, and $7 \mathrm{~nm}$ simple box systems.

\begin{tabular}{|c|c|c|c|c|}
\hline Systems & Adsorption Energy & Rigid Adsorption Energy & Deformation Energy & Congo Red: $\mathrm{dE}_{\mathrm{ad}} / \mathrm{dN}_{\mathrm{i}}$ \\
\hline $3 \mathrm{~nm}$ & -41.22350801 & -31.58960227 & -8.63390575 & -41.22350801 \\
\hline $5 \mathrm{~nm}$ & -39.83882700 & -28.74763343 & -10.09119357 & -39.83882700 \\
\hline $7 \mathrm{~nm}$ & -37.15356471 & -27.49577995 & -15.65778476 & -37.15356471 \\
\hline
\end{tabular}

\subsection{Field Experiment and Comparison with Other Adsorbents}

Optimized parameters for the newly synthesized ZAS adsorbent including adsorbent weight $(0.02 \mathrm{gm})$, near room temperature, the $\mathrm{pH}$ of the wastewater containing waste dye remained as it is without any changes, and contact time was $420 \mathrm{~min}$. Scanning of wavelengths found in the as-received industrial wastewater revealed the presence of different wavelengths corresponding to different dyes. At the end of contact time, absorbance at different wavelengths was recorded to calculate the removal efficiency of the dyes from industrial wastewater. The data showed that the ZAS adsorbent extracted dyes from industrial wastewater with a $98.0 \%$ efficiency, validating the foundation of modern eco-friendly adsorbents that help with the reuse of industrial wastewater. 
The adsorption capacities, $\mathrm{q}_{\mathrm{m}}$, and removal percentages of different zeolite-based adsorbents reported in the literature were compared with that of Z, AS, and ZAS for adsorption of $C R$ dye and are shown in Table 4 . It shows that $\mathrm{q}_{\mathrm{m}}$ values vary broadly for different adsorbents [87-92]. The results stated that Z, AS, and ZAS displayed a reasonable adsorption capacity for adsorption of $C R$ dye from aqueous solutions in comparison with other adsorbents [87-92]. Moreover, according to the simple procedure that was used for the preparation of ZAS composite, availability, and price of both the $\mathrm{Z}$ and AS, the estimated cost of the preparation process of the ZAS composite is $1.5-2.0 \mathrm{USD} / \mathrm{kg}$, which is very cheap if compared to the other adsorbents that reported in Table 4.

Table 4. Comparison of the optimized conditions, removal\%, and adsorption capacity of different zeolite-based CR adsorbents relative to our Z, AS, and ZAS nanoadsorbents.

\begin{tabular}{|c|c|c|c|c|}
\hline Adsorbent & Conditions & $\begin{array}{l}\text { Adsorption Capacity }\left(\mathrm{q}_{\mathrm{m}}\right) \\
(\mathrm{mg} / \mathrm{g})\end{array}$ & Removal\% & Reference \\
\hline Zeolite & $\begin{array}{c}\text { Concentration: } 200 \mathrm{mg} / \mathrm{L} \\
\text { Dosage: } 10 \mathrm{~g} / 100 \mathrm{~mL} \\
\text { pH: } 3 \\
\text { Temperature: } 25{ }^{\circ} \mathrm{C}\end{array}$ & 4.3 & $95 \%$ & [87] \\
\hline ZnO@Ze Composite & $\begin{array}{c}\text { Concentration: } 100 \mathrm{mg} / \mathrm{L} \\
\text { Dose: } 50 \mathrm{mg} \\
\text { pH: } 3 \\
\text { Temperature: } 25^{\circ} \mathrm{C} \\
\text { Time: } 60 \mathrm{~min} \\
\text { Concentration: } 30 \mathrm{mg} / \mathrm{L}\end{array}$ & 161.3 & $99.5 \%$ & [88] \\
\hline SMZ6 & $\begin{array}{c}\text { Dose: } 40 \mathrm{mg} \\
\text { pH: } 6 \\
\text { Temperature: } 20-40{ }^{\circ} \mathrm{C} \\
\text { Time: } 24 \mathrm{~h}\end{array}$ & 69.94 & $98.7 \%$ & [89] \\
\hline $\begin{array}{c}\text { PVA/SA/ZSM-5 } \\
\text { zeolite membrane }\end{array}$ & $\begin{array}{c}\text { Concentration: } 10 \mathrm{ppm} \\
\text { Dosage: } 2.5 \mathrm{wt} \% \\
\text { pH: } 3 \\
\text { Temperature: } 30{ }^{\circ} \mathrm{C} \\
\text { Time: } 130 \mathrm{~min}\end{array}$ & 5.33 & $99.3 \%$ & [90] \\
\hline $\begin{array}{l}\text { Na-zeolite@chitosan } \\
\text { nanoparticle }\end{array}$ & $\begin{array}{c}\text { Concentration: } 800 \mathrm{ppm} \\
\text { Dose: } 0.1 \mathrm{~g} \\
\text { pH: } 5 \\
\text { Temperature: } 25^{\circ} \mathrm{C} \\
\text { Time: } 60 \mathrm{~min}\end{array}$ & $0.00428 \mathrm{mmol} / \mathrm{g}$ & $98.019 \%$ & [91] \\
\hline $\begin{array}{c}\text { Cu(II)-incorporated } \\
\text { zeolite } Y\end{array}$ & $\begin{array}{c}\text { Concentration: } 10 \mathrm{mg} / \mathrm{L} \\
\text { Dosage: } 1.5 \mathrm{~g} / \mathrm{L} \\
\text { pH: } 7 \\
\text { At room temperature } \\
\text { Time: } 240 \mathrm{~min}\end{array}$ & - & $87.72 \%$ & [92] \\
\hline $\mathrm{Z}$ & $\begin{array}{l}\text { Contact time: } 480 \mathrm{~min} \\
\text { adsorbent dose: } 0.02 \mathrm{~g}\end{array}$ & 8.17 & 65 & \\
\hline AS & Concentration: $20 \mathrm{mg} / \mathrm{L}$ & 15 & 98.68 & This work \\
\hline ZAS & $\begin{array}{c}\text { pH: } 7 \\
\text { Temp: } 25^{\circ} \mathrm{C}\end{array}$ & 16.07 & 99.9 & \\
\hline
\end{tabular}

\section{Conclusions}

The hydrothermal treatment of $\mathrm{Z}$ and AS yielded a novel alga / zeolite composite (ZAS) which was used as a new adsorbent for CR from an aqueous solution. The experimental results demonstrated that decreasing the initial CR concentration increased the CR removal\% and that the CR removal rate is high during the early stages of the adsorption experiment. The removal\% increased by increasing Z, AS, and ZAS dosage from $0.01 \mathrm{~g}$ to $0.05 \mathrm{~g}$. The temperature has a significant impact on the CR elimination percentage. The CR removal 
percent increased for all adsorbents as the initial $\mathrm{pH}$ of the CR solution was changed from 3 to 10 , with the highest adsorption occurring at $\mathrm{pH} 7$. The catalytic performances of $Z$, AS, and ZAS adsorbents were reduced to $28.6 \%, 30.0 \%$, and $61.7 \%$ at the fourth cycle, respectively, in the reducibility test, indicating that the ZAS is more reusable as a catalyst than its components. The adsorption isotherm of $C R$ onto $Z, A S$, and ZAS shows that $Z$, AS, and ZAS adsorbents track the Langmuir isotherm model. The CR adsorption onto $Z$, AS, and ZAS is well handled with the second-order model. The intra-particle diffusion kinetics model's intercept is not zero, indicating that the intra-particle diffusion model may not be the main rate-controlling element in determining adsorption kinetics. Further studies are needed to look into the effects of dissolved salts on the adsorption behaviors of zeolite and ZAS composite, as well as the examination of more composites with varying ratios of the individual components.

Supplementary Materials: The following are available online at https:/ /www.mdpi.com/article/10 $.3390 /$ nano11092441/s1, Table S1: Conditions of experimental adsorption tests; Figure S1: Structure of Congo red; Figure S2. DLS spectra of Z, AS, and ZAS adsorbents; Figure S3. The adsorption configurations of adsorbed $\mathrm{CR}$ on zeolite clinoptilolite of 3,5 , and $7 \mathrm{~nm}$ simple box systems for clarity purposes.

Author Contributions: Conceptualization, A.H. and M.S.; methodology, A.H., A.R.D., H.A., and M.S.; validation, A.H., A.R.D., and M.S.; formal analysis, A.H., A.R.D., H.A., K.A.A.A.-O., N.K.S., S.A.A., and M.S.; investigation, A.H. and M.S.; resources, A.H., A.R.D., H.A., K.A.A.A.-O., and M.S.; data curation, A.H., A.R.D., N.K.S., S.A.A., and M.S.; writing—original draft preparation, A.H., A.R.D., N.K.S., and M.S.; writing - review and editing, A.H., N.K.S., and M.S.; visualization, A.H. and M.S.; project administration, H.A., K.A.A.A.-O., and M.S.; funding acquisition, H.A., A.H., and M.S. All authors have read and agreed to the published version of the manuscript.

Funding: This research received funding from the Scientific Research Deanship, the Islamic University of Madinah with Tamayyuz 2 grant number 585 (2020/2021).

Data Availability Statement: Data can be available upon request from the authors.

Acknowledgments: The authors would like to thank the Scientific Research Deanship, the Islamic University of Madinah, for the support provided, with Tamayyuz 2 grant number 585 (2020/2021).

Conflicts of Interest: The authors declare no conflict of interest.

\section{References}

1. Yadav, V.G. Dyes for the next millennium. Colourage 1998, 45, 53-56.

2. Kant, R. Textile dyeing industry an environmental hazard. Nat. Sci. 2012, 4, 22-26. [CrossRef]

3. Mohamed, H.S.; Soliman, N.; Moustafa, A.; Abdel-Gawad, O.F.; Taha, R.R.; Ahmed, S.A. Nano metal oxide impregnated Chitosan-4-nitroacetophenone for industrial dye removal. Int. J. Environ. Anal. Chem. 2019, 1-28. [CrossRef]

4. Soliman, N.; Mohamed, H.; Elsayed, R.; Elmedny, N.M.; Elghandour, A.H.; Ahmed, S.A. Removal of chromium and cadmium ions from aqueous solution using residue of Rumex dentatus L. plant waste. Desalination Water Treat. 2019, 149, 181-193. [CrossRef]

5. Soliman, N.; Mohamed, H.; Ahmed, S.A.; Sayed, F.H.; Elghandour, A.H.; Ahmed, S.A. Cd2+ and Cu2+ removal by the waste of the marine brown macroalga Hydroclathrus clathratus. Environ. Technol. Innov. 2019, 15, 100365. [CrossRef]

6. Da'Na, E. Adsorption of heavy metals on functionalized-mesoporous silica: A review. Microporous Mesoporous Mater. 2017, 247, 145-157. [CrossRef]

7. Anderson, K.; Ryan, B.; Sonntag, W.; Kavvada, A.; Friedl, L. Earth observation in service of the 2030 Agenda for Sustainable Development. Geo-spatial Inf. Sci. 2017, 20, 77-96. [CrossRef]

8. Christie, R.M. Environmental Aspects of Textile Dyeing, 1st ed.; Elsevier: Amsterdam, The Netherlands, 2007; ISBN 978-184-569-115-8.

9. Bae, J.-S.; Freeman, H.S. Aquatic toxicity evaluation of new direct dyes to the Daphnia magna. Dye. Pigment. 2005, 73, 81-85. [CrossRef]

10. Lehr, J.H.; Gass, T.E.; Pettyjohn, W. Domestic Water Treatment. McGraw Hill Book Co.: New York, NY, USA, 1980 ; p. 272. ISBN 978-156-034-007-2.

11. Nemerow, N.L. Industrial Water Pollution. Origins Characteristics and Treatment; Addison-Wesley Publishing Co.: Reading, MA, USA, 1978; Volume 4, p. 738. ISBN 978-020-105-246-6.

12. Gupta, V.K. Application of low-cost adsorbents for dye removal-A review. J. Environ. Manag. 2009, 90, 2313-2342. [CrossRef]

13. Yagub, M.T.; Sen, T.K.; Afroze, S.; Ang, H. Dye and its removal from aqueous solution by adsorption: A review. Adv. Colloid Interface Sci. 2014, 209, 172-184. [CrossRef] 
14. Foroughi-Dahr, M.; Abolghasemi, H.; Esmaili, M.; Shojamoradi, A.; Fatoorehchi, H. Adsorption Characteristics of Congo Red from Aqueous Solution onto Tea Waste. Chem. Eng. Commun. 2014, 202, 181-193. [CrossRef]

15. Shaban, M.; Abukhadra, M.R. Geochemical evaluation and environmental application of Yemeni natural zeolite as sorbent for $\mathrm{Cd}^{2+}$ from solution: Kinetic modeling, equilibrium studies, and statistical optimization. Environ. Earth Sci. 2017, 76, 310. [CrossRef]

16. Shaban, M.; Elwahab, F.A.; Ghitas, A.E.; El Zayat, M.Y. Efficient and recyclable photocatalytic degradation of methylene blue dye in aqueous solutions using nanostructured Cd1-xCoxS films of different doping levels. J. Sol-Gel Sci. Technol. 2020, 95, 276-288. [CrossRef]

17. Shaban, M.; Abdallah, H.; Said, L.; Ahmed, A.M. Water desalination and dyes separation from industrial wastewater by PES/ $\mathrm{TiO}_{2} \mathrm{NTs}$ mixed matrix membranes. J. Polym. Res. 2019, 26, 181. [CrossRef]

18. Doğan, M.; Alkan, M.; Demirbaş, Ö.; Özdemir, Y.; Özmetin, C. Adsorption kinetics of maxilon blue GRL onto sepiolite from aqueous solutions. Chem. Eng. J. 2006, 124, 89-101. [CrossRef]

19. El Qada, E.N.; Allen, S.J.; Walker, G. Adsorption of Methylene Blue onto activated carbon produced from steam activated bituminous coal: A study of equilibrium adsorption isotherm. Chem. Eng. J. 2006, 124, 103-110. [CrossRef]

20. Shaban, M.; Sayed, M.I.; Shahien, M.G.; Abukhadra, M.R.; Ahmed, Z.M. Adsorption behavior of inorganic- and organ-ic-modified kaolinite for Congo red dye from water, kinetic modeling, and equilibrium studies. J. Sol-Gel Sci. Technol. 2018, 87, 427-441. [CrossRef]

21. Anjaneyulu, Y.; Chary, N.S.; Raj, D.S.S. Decolourization of industrial effluents-Available methods and emerging technolo-giesA review. Rev. Environ. Sci. Bio/Technol. 2005, 4, 245-273. [CrossRef]

22. Ghaedi, M.; Shokrollahi, A.; Tavallali, H.; Shojaiepoor, F.; Keshavarz, B.; Hossainian, H.; Soylak, M.; Purkait, M.K. Activated carbon and multiwalled carbon nanotubes as efficient adsorbents for removal of arsenazo(III) and methyl red from waste water. Toxicol. Environ. Chem. 2010, 93, 438-449. [CrossRef]

23. Gainanova, A.A.; Domoroshchina, E.N.; Kuz'Micheva, G.M.; Khramov, E.V.; Chumakov, R.G.; Gotovtsev, P.M.; Pirutko, L.V.; Zybinskiy, A.M.; Yashina, N.V. New composites based on zeolites (H-Beta, H-ZSM-5) and nanosized titanium(iv) oxide (anatase and $\eta$-phase) doped by Ni, Ag, V with photocatalytic, adsorption and bactericidal properties. New J. Chem. 2020, 45, 2417-2430. [CrossRef]

24. Maharana, M.; Manna, M.; Sardar, M.; Sen, S. Heavy metal removal by low-cost adsorbents. In Green Adsorbents to Remove Metals, Dyes and Boron from Polluted Water, 1st ed.; Mohd Imran Ahamed, I., Lichtfouse, E., Asiri, A.M., Eds.; Springer: Berlin, Germany, 2021; pp. 245-272. ISBN 978-3-030-47399-0.

25. El-Zeiny, H.M.; Abukhadra, M.R.; Sayed, O.; Osman, A.H.; Ahmed, S.A. Insight into novel $\beta$-cyclodextrin-grafted-poly (N-vinylcaprolactam) nanogel structures as advanced carriers for 5-fluorouracil: Equilibrium behavior and pharmacokinetic modeling. Colloids Surf. A Physicochem. Eng. Asp. 2019, 586, 124197. [CrossRef]

26. Selim, A.Q.; Sellaoui, L.; Ahmed, S.A.; Mobarak, M.; Mohamed, E.A.; Ben Lamine, A.; Erto, A.; Bonilla-Petriciolet, A.; Seliem, M.K. Statistical physics-based analysis of the adsorption of $\mathrm{Cu}^{2+}$ and $\mathrm{Zn}^{2+}$ onto synthetic cancrinite in single-compound and binary systems. J. Environ. Chem. Eng. 2019, 7, 103217. [CrossRef]

27. Mohamed, F.; Abukhadra, M.R.; Shaban, M. Removal of safranin dye from water using polypyrrole nanofiber/Zn-Fe layered double hydroxide nanocomposite (Ppy NF/Zn-Fe LDH) of enhanced adsorption and photocatalytic properties. Sci. Total Environ. 2018, 640-641, 352-363. [CrossRef]

28. Alabdly, H.A.; Al-Nuaemi, I.J.; Al Ani, H.N.A.; Cotorcea, S.; Nechifor, A.C. Removal of Toxic Phenolic Compounds from Wastewater Using Zeolite (4A) Prepared from Local Clays Taken from the Slopes of the Tigris River. Rev. Chim. 2021, 72, 44-52. [CrossRef]

29. Sabonian, M.; Mahanpoor, K. Photocatalytic Degradation of Dye Pollutant in Synthetic Wastewater by Nano-Fe3O4 Based on Clinoptilolite Zeolite. Arch. Hyg. Sci. 2021, 10, 1-10. [CrossRef]

30. Dosa, M.; Piumetti, M.; Davarpanah, E.; Moncaglieri, G.; Bensaid, S.; Fino, D. Natural zeolites as sustainable materials for environmental processes. In Nanostructured Catalysts for Environmental Applications; Springer: Berlin, Germany, 2021; pp. 367-381. ISBN 978-3-030-58933-2.

31. Gayatri, R.; Agustina, T.E.; Moeksin, R.; Bahrin, D.; Gustini, G. Preparation and Characterization of ZnO-Zeolite Nanocomposite for Photocatalytic Degradation by Ultraviolet Light. J. Ecol. Eng. 2021, 22, 178-186. [CrossRef]

32. Narayanan, S.; Tamizhdurai, P.; Mangesh, V.L.; Ragupathi, C.; Krishnan, P.S.; Ramesh, A. Recent advances in the synthesis and applications of mordenite zeolite-Review. RSC Adv. 2020, 11, 250-267. [CrossRef]

33. Wang, S.; Peng, Y. Natural zeolites as effective adsorbents in water and wastewater treatment. Chem. Eng. J. 2010, 156, 11-24. [CrossRef]

34. Reeve, P.J.; Fallowfield, H. Natural and surfactant modified zeolites: A review of their applications for water remediation with a focus on surfactant desorption and toxicity towards microorganisms. J. Environ. Manag. 2018, 205, 253-261. [CrossRef] [PubMed]

35. Altintig, E.; Alsancak, A.; Karaca, H.; Angın, D.; Altundag, H. The comparison of natural and magnetically modified zeolites as an adsorbent in methyl violet removal from aqueous solutions. Chem. Eng. Commun. 2021, 1-15. [CrossRef]

36. Shaban, M.; Abukhadra, M.R.; Shahien, M.G.; Ibrahim, S.S. Novel bentonite/zeolite-NaP composite efficiently removes methylene blue and Congo red dyes. Environ. Chem. Lett. 2017, 16, 275-280. [CrossRef] 
37. Saqib, N.U.; Adnan, R.; Rahim, M.; Khan, A. Low-cost Zeolite $/ \mathrm{TiO}_{2}$ composite for the photocatalytically enhanced adsorption of $\mathrm{Cd}^{2+}$ from aqueous solution. J. Iran. Chem. Soc. 2021, 1-16. [CrossRef]

38. Harja, M.; Buema, G.; Lupu, N.; Chiriac, H.; Herea, D.D.; Ciobanu, G. Fly Ash Coated with Magnetic Materials: Improved Adsorbent for $\mathrm{Cu}$ (II) Removal from Wastewater. Materials 2020, 14, 63. [CrossRef]

39. Shankhadarwar, S.D. Phytochemical analysis of red alga Acanthophora spicifera (Vahl) collected from Mumbai, India. J. Chem. Pharm. Res. 2015, 7, 441-444.

40. Marzbali, M.H.; Mir, A.A.; Pazoki, M.; Pourjamshidian, R.; Tabeshnia, M. Removal of direct yellow 12 from aqueous solution by adsorption onto spirulina algae as a high-efficiency adsorbent. J. Environ. Chem. Eng. 2017, 5, 1946-1956. [CrossRef]

41. Khedr, M.; Halim, K.A.; Soliman, N. Effect of temperature on the kinetics of acetylene decomposition over reduced iron oxide catalyst for the production of carbon nanotubes. Appl. Surf. Sci. 2008, 255, 2375-2381. [CrossRef]

42. Khedr, M.H.; Nasr, M.I.; Abdel Halim, K.S.; Farghali, A.A.; Soliman, N.K. Catalytic decomposition of hydrocarbon gas over various nanostructured metal oxides for hydrocarbon removal and production of carbon nanotubes. Int. J. Eng. Res. Gen. Sci. 2014, 2, 413-424.

43. Shaban, M.; Mustafa, M.; El Sayed, A. Structural, optical, and photocatalytic properties of the spray deposited nanoporous CdS thin films; influence of copper doping, annealing, and deposition parameters. Mater. Sci. Semicond. Process. 2016, 56, 329-343. [CrossRef]

44. Shaban, M.; Abukhadra, M.R.; Hamd, A.; Amin, R.R.; Khalek, A.A. Photocatalytic removal of Congo red dye using MCM$48 / \mathrm{Ni}_{2} \mathrm{O}_{3}$ composite synthesized based on silica gel extracted from rice husk ash; fabrication and application. J. Environ. Manag. 2017, 204, 189-199. [CrossRef]

45. Soliman, N.K.; Moustafa, A.F.; Aboud, A.A.; Halim, K.S.A. Effective utilization of Moringa seeds waste as a new green environmental adsorbent for removal of industrial toxic dyes. J. Mater. Res. Technol. 2019, 8, 1798-1808. [CrossRef]

46. Freundlich, H. Over the adsorption in solution. J. Phys. Chem. 1906, 57, 1100-1107.

47. Temkin, M. Kinetics of ammonia synthesis on promoted iron catalysts. Acta Physiochim. URSS 1940, 12, 327-356.

48. Foo, K.Y.; Hameed, B.H. Insights into the modeling of adsorption isotherm systems. Chem. Eng. J. 2010, 156, 2-10. [CrossRef]

49. Ozdemir, O.; Armagan, B.; Turan, M.; Çelik, M.S. Comparison of the adsorption characteristics of azo-reactive dyes on mezoporous minerals. Dye. Pigment. 2004, 62, 49-60. [CrossRef]

50. Xin, N.; Gu, X.; Wu, H.; Hu, Y.; Yang, Z. Application of genetic algorithm-support vector regression (GA-SVR) for quantitative analysis of herbal medicines. J. Chemom. 2012, 26, 353-360. [CrossRef]

51. Mohamed, H.; Soliman, N.; Abdelrheem, D.A.; Ramadan, A.A.; Elghandour, A.H.; Ahmed, S.A. Adsorption of $\mathrm{Cd}^{2+}$ and Cr ${ }^{3+}$ ions $^{2}$ from aqueous solutions by using residue of padina gymnospora waste as promising low-cost adsorbent. Heliyon 2019 , 5, e01287. [CrossRef]

52. Fan, L.; Luo, C.; Sun, M.; Qiu, H.; Li, X. Synthesis of magnetic $\beta$-cyclodextrin-chitosan/graphene oxide as nanoadsorbent and its application in dye adsorption and removal. Colloids Surfaces B Biointerfaces 2013, 103, 601-607. [CrossRef]

53. Demiral, H.; Gündüzoğlu, G. Removal of nitrate from aqueous solutions by activated carbon prepared from sugar beet bagasse. Bioresour. Technol. 2010, 101, 1675-1680. [CrossRef]

54. Rady, D.; Shaban, M.; Elsayed, K.N.M.; Hamd, A.; Soliman, N.K.; El-Mageed, H.R.A.; Elzanaty, A.M.; El-Sayed, R.; Morada, M.; El-Bahy, S.M.; et al. Experimentally and theoretically approaches for Congo red dye adsorption on novel kaolinite-alga nano-composite. Int. J. Environ. Anal. Chem. 2021, 1-23. [CrossRef]

55. Wu, F.-C.; Tseng, R.-L.; Juang, R.-S. Initial behavior of intraparticle diffusion model used in the description of adsorption kinetics. Chem. Eng. J. 2009, 153, 1-8. [CrossRef]

56. Delley, B. An all-electron numerical method for solving the local density functional for polyatomic molecules. J. Chem. Phys. 1990, 92, 508-517. [CrossRef]

57. Delley, B. From molecules to solids with the DMol3 approach. J. Chem. Phys. 2000, 113, 7756-7764. [CrossRef]

58. Rao, Z.-H.; Wang, S.F.; Zhang, Y.L.; Peng, F.F.; Cai, S.H. Molecular dynamics simulation of the thermophysical properties of phase change material. Acta Phys. Sin. 2013, 62, 056601.

59. Uzunova, E.L.; Mikosch, H. Adsorption and Activation of Ethene in Transition Metal Exchanged Zeolite Clinoptilolite: A Density Functional Study. ACS Catal. 2013, 3, 2759-2767. [CrossRef]

60. Frenkel, D.; Smit, B. Understanding Molecular Simulation: From Algorithms to Applications; Elsevier: Amsterdam, The Netherlands, 2002; pp. 1-638. ISBN 978-0-12-267351-1.

61. Gougazeh, M.; Buhl, J.-C. Synthesis and characterization of zeolite A by hydrothermal transformation of natural Jordanian kaolin. J. Assoc. Arab. Univ. Basic Appl. Sci. 2014, 15, 35-42. [CrossRef]

62. Treacy, M.M.; Higgins, J.B. Collection of Simulated XRD Powder Patterns for Zeolites, 5th ed.; Elsevier: Amsterdam, The Netherlands, 2007; ISBN 978-044-453-067-7.

63. Sivakumar, S.R.; Arunkumar, K. Sodium, Potassium and Sulphate Composition in Some Seaweeds Occurring along the Coast of Gulf of Mannar, India. Asian J. Plant Sci. 2009, 8, 500-504. [CrossRef]

64. Pi, Z.; Liu, Z.; Yang, C.; Tian, X.; Fei, J.; Zheng, J. Exfoliation of kaolinite by urea-intercalation precursor and microwave irradiation assistance process. Front. Earth Sci. China 2007, 1, 26-29. [CrossRef]

65. Vaculikova, L.; Plevova, E.; Vallova, S.; Koutnik, I. Characterization and differentiation of kaolinites from selected Czech deposits using infrared spectroscopy and differential thermal analysis. Acta Geodyn. Geromater. 2011, 8, 59. 
66. Horváth, E.; Kristóf, J.; Frost, R.L. Vibrational Spectroscopy of Intercalated Kaolinites. Part I. Appl. Spectrosc. Rev. 2010, 45, 130-147. [CrossRef]

67. Madejova, J. Baseline Studies of the Clay Minerals Society Source Clays: Infrared Methods. Clays Clay Miner. 2001, 49, 410-432. [CrossRef]

68. Masoudi, R.; Moghimi, H.; Azin, E.; Taheri, R.A. Adsorption of cadmium from aqueous solutions by novel $\mathrm{Fe}_{3} \mathrm{O}_{4}{ }^{-}$newly isolated actinomucor sp. bio-nanoadsorbent: Functional group study. Artif. Cells Nanomed. Biotechnol. 2018, 46, S1092-S1101. [CrossRef]

69. Nautiyal, P.; Subramanian, K.; Dastidar, M. Adsorptive removal of dye using biochar derived from residual algae after in-situ transesterification: Alternate use of waste of biodiesel industry. J. Environ. Manag. 2016, 182, 187-197. [CrossRef] [PubMed]

70. Ghoneim, M.M.; El-Desoky, H.S.; El-Moselhy, K.M.; Amer, A.; El-Naga, E.H.A.; Mohamedein, L.; Al-Prol, A.E. Removal of cadmium from aqueous solution using marine green algae, Ulva lactuca. Egypt. J. Aquat. Res. 2014, 40, 235-242. [CrossRef]

71. Ibrahim, W.M.; Hassan, A.F.; Azab, Y.A. Biosorption of toxic heavy metals from aqueous solution by Ulva lactuca activated carbon. Egypt. J. Basic Appl. Sci. 2016, 3, 241-249. [CrossRef]

72. Mohamed, F.; Allah, A.E.; Abu Al-Ola, K.; Shaban, M. Design and Characterization of a Novel ZnO-Ag/Polypyrrole Core-Shell Nanocomposite for Water Bioremediation. Nanomaterials 2021, 11, 1688. [CrossRef]

73. Sharma, Y.C. Uma Optimization of Parameters for Adsorption of Methylene Blue on a Low-Cost Activated Carbon. J. Chem. Eng. Data 2009, 55, 435-439. [CrossRef]

74. Tahir, M.A.; Bhatti, H.N.; Iqbal, M. Solar Red and Brittle Blue direct dyes adsorption onto Eucalyptus angophoroides bark: Equilibrium, kinetics and thermodynamic studies. J. Environ. Chem. Eng. 2016, 4, 2431-2439. [CrossRef]

75. Abukhadra, M.R.; Shaban, M. Recycling of different solid wastes in synthesis of high-order mesoporous silica as adsorbent for safranin dye. Int. J. Environ. Sci. Technol. 2019, 16, 7573-7582. [CrossRef]

76. Pons, M.P. Uranium uptake by immobilized cells of Pseudomonas strain EPS 5028. Appl. Microbiol. Biotechnol. 1993, 39, 661-665. [CrossRef]

77. Shaban, M.; Abukhadra, M.R.; Khan, A.A.P.; Jibali, B.M. Removal of Congo red, methylene blue and Cr(VI) ions from water using natural serpentine. J. Taiwan Inst. Chem. Eng. 2018, 82, 102-116. [CrossRef]

78. Salleh, M.A.M.; Mahmoud, D.K.; Karim, W.A.W.A.; Idris, A. Cationic and anionic dye adsorption by agricultural solid wastes: A comprehensive review. Desalination 2011, 280, 1-13. [CrossRef]

79. Santosa, S.J. Sutarno Adsorption of Congo Red Dye on HDTMA Surfactant-Modified Zeolite A Synthesized from Fly Ash. Defect Diffus. Forum 2018, 382, 307-311. [CrossRef]

80. Zhang, J.; Zhou, Q.; Ou, L. Kinetic, Isotherm, and Thermodynamic Studies of the Adsorption of Methyl Orange from Aqueous Solution by Chitosan/Alumina Composite. J. Chem. Eng. Data 2011, 57, 412-419. [CrossRef]

81. Noreen, S.; Bhatti, H.N.; Zuber, M.; Zahid, M.; Asgher, M. Removal of Actacid Orange-RL Dye Using Biocomposites: Modeling Studies. Pol. J. Environ. Stud. 2017, 26, 2125-2134. [CrossRef]

82. Mushtaq, M.; Bhatti, H.N.; Iqbal, M.; Noreen, S. Eriobotrya japonica seed biocomposite efficiency for copper adsorption: Isotherms, kinetics, thermodynamic and desorption studies. J. Environ. Manag. 2016, 176, 21-33. [CrossRef]

83. Rashid, A.; Bhatti, H.N.; Iqbal, M.; Noreen, S. Fungal biomass composite with bentonite efficiency for nickel and zinc adsorption: A mechanistic study. Ecol. Eng. 2016, 91, 459-471. [CrossRef]

84. Naghizadeh, A. Regeneration of Carbon Nanotubes Exhausted with Humic Acid Using Electro-Fenton Technology. Arab. J. Sci. Eng. 2015, 41, 155-161. [CrossRef]

85. Hall, K.R.; Eagleton, L.C.; Acrivos, A.; Vermeulen, T. Pore- and Solid-Diffusion Kinetics in Fixed-Bed Adsorption under ConstantPattern Conditions. Ind. Eng. Chem. Fundam. 1966, 5, 212-223. [CrossRef]

86. Weber, W.J.; Morris, J.C. Kinetics of adsorption on carbon from solution. J. Sanit. Eng. Div. 1963, 89, 31-60. [CrossRef]

87. Vimonses, V.; Lei, S.; Jin, B.; Chow, C.; Saint, C. Kinetic study and equilibrium isotherm analysis of Congo Red adsorption by clay materials. Chem. Eng. J. 2009, 148, 354-364. [CrossRef]

88. Madan, S.; Shaw, R.; Tiwari, S.; Tiwari, S.K. Adsorption dynamics of Congo red dye removal using ZnO functionalized high silica zeolitic particles. Appl. Surf. Sci. 2019, 487, 907-917. [CrossRef]

89. Liu, S.; Ding, Y.; Li, P.; Diao, K.; Tan, X.; Lei, F.; Zhan, Y.; Li, Q.; Huang, B.; Huang, Z. Adsorption of the anionic dye Congo red from aqueous solution onto natural zeolites modified with $\mathrm{N}, \mathrm{N}$-dimethyl dehydroabietylamine oxide. Chem. Eng. J. 2014, 248, 135-144. [CrossRef]

90. Radoor, S.; Karayil, J.; Parameswaranpillai, J.; Siengchin, S. Removal of anionic dye Congo red from aqueous environment using polyvinyl alcohol/sodium alginate/ZSM-5 zeolite membrane. Sci. Rep. 2020, 10, 1-15. [CrossRef] [PubMed]

91. Yulizar, Y.; Utari, T.; Apriandanu, D.O.B.; Putri, Y.R.P. Chitosan nanoparticles on a natural zeolite as an efficient adsorbent for Congo red. IOP Conf. Series Mater. Sci. Eng. 2019, 496, 012005. [CrossRef]

92. Chowdhury, S.; Bhattacharyya, K.G. Use of $\mathrm{Cu}(\mathrm{II})$-incorporated zeolite $\mathrm{Y}$ for decolourization of dyes in water: A case study with aqueous methylene blue and Congo red. SN Appl. Sci. 2018, 1, 87. [CrossRef] 